\title{
Inorganic Asymmetric Synthesis: Asymmetric Synthesis of a Two-Bladed Propeller, Octahedral Metal Complex
}

\author{
Rebecca J. Warr, Anthony C. Willis, and S. Bruce Wild* \\ Research School of Chemistry, Institute of Advanced Studies, Australian National University, \\ Canberra, ACT 0200, Australia \\ Received May 18, 2006
}

\begin{abstract}
A $C_{2}$ hexadentate, in which two pyridine-2-aldehyde 2'-pyridylhydrazone (PAPHY) groups are linked to a chiral auxiliary derived from $(R, R)$-tartaric acid, $(R, R)-1$, reacts with iron(II) benzenesulfonate to give the two-bladed propeller, octahedral complex $\left(P_{\mathrm{Fe}}\right)-[\mathrm{Fe}\{(R, R)-1\}]\left(\mathrm{PhSO}_{3}\right)_{2}$ with complete diastereoselectivity, as determined by ${ }^{1} \mathrm{H} \mathrm{NMR}$ spectroscopy and $\mathrm{X}$-ray crystallography. Saponification of the ester linkages and deprotonation of the hydrazone$\mathrm{NH}$ groups in the configurationally pure diastereomer affords the complex $\left(P_{\mathrm{Fe}}\right)-\left[\mathrm{Fe}\left(5-\mathrm{HOCH}_{2} \mathrm{PAPY}\right)_{2}\right]$ with $85 \%$ retention of configuration at the iron stereocenter, as determined by reprotonation of the neutral complex with enantiomerically pure $(\mathrm{a} R)$-binaphthyl phosphoric acid and analysis of the ${ }^{1} \mathrm{H}$ NMR spectrum of the mixture of diastereomeric salts produced. This is the first asymmetric synthesis of a two-bladed propeller, octahedral metal complex by the classical organic methodology of chiral auxiliary-directed, asymmetric synthesis.
\end{abstract}

\section{Introduction}

There are now modifications available for nearly every standard organic reaction for converting achiral precursors into chiral products; when combined with modern purification techniques, this has allowed the synthesis and isolation of chiral organic molecules in almost complete enantiomeric purity for many reaction types. The field of inorganic asymmetric synthesis is far less developed, despite the importance of configurationally pure metal complexes in biology and for the elucidation of inorganic rearrangements and reaction mechanisms. For example, the bacterial siderophore enterobactin, a naturally occurring hexadentate in which three chelating catecholamide groups are suspended from a $C_{3}$-chiral triserine lactone scaffold, chelates iron(III) to give a single diastereomer of a remarkably stable complex in which the three-bladed propeller, octahedral, tris(catecholato)iron(III) stereocenter has the $\Delta$ configuration; structurally similar corynebactin, however, which has a $C_{3}$-chiral threonine lactone scaffold and glycine spacers between the three catachol groups and the lactone ring, sequesters iron(III) to give a complex in which the iron(III) stereocenter has the $\Lambda$ configuration. ${ }^{1}$ The $C_{3}$-scaffold methodology has been applied to the diastereoselective synthesis of tris(hydroxamato)-

* To whom correspondence should be addressed. E-mail: sbw@rsc.anu.edu.au.

(1) Raymond, K. N.; Dertz, E. A.; Kim, S. S. Proc. Natl. Acad. Sci. U.S.A. 2003, 100, 3584-3588.

8618 Inorganic Chemistry, Vol. 45, No. 21, 2006
chromium(III) and tris(bipyridine)ruthenium(II) complexes by the incorporation of three $(S)$-alanine groups into the backbones of appropriate $C_{3}$ hexadentate ligands ${ }^{2}$ and to the syntheses of di- and trinuclear copper(I) helicates containing 2,2'-bipyridine units with use of $C_{2}$ scaffolds derived from enantiomerically pure spirocycles and atropisomers. ${ }^{3}$ In these diastereoselective reactions, the chiral scaffolds, be they the 12-membered lactone rings in the natural siderophores or the chiral centers or axes in the artificial systems, remain in the products containing the newly created chiral metal sterocenters. For a true asymmetric synthesis, the chiral auxiliary must be removed from the product. This has not been achieved in the above chiral-scaffold syntheses, although there is in the literature a report of the asymmetric synthesis of $\Delta$-[Co(bpy $\left.)_{3}\right]\left(\mathrm{NO}_{3}\right)_{3}$ by the silver nitrate oxidation of an equilibrating mixture of cobalt(II) complexes containing boronic acid-substituted bipyridine ligands in the presence of $(R)$-allose. ${ }^{4}$

The unsymmetrical tridentate pyridine-2-aldehyde 2'pyridylhydrazone (PAPHY) is a powerful chelating agent

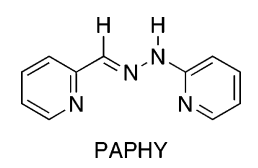

for most first-row, divalent, transition metal ions, forming stable two-bladed propeller, octahedral complexes of the type 10.1021/ic060856q CCC: $\$ 33.50$

(C) 2006 American Chemical Society Published on Web 09/22/2006 
Scheme 1

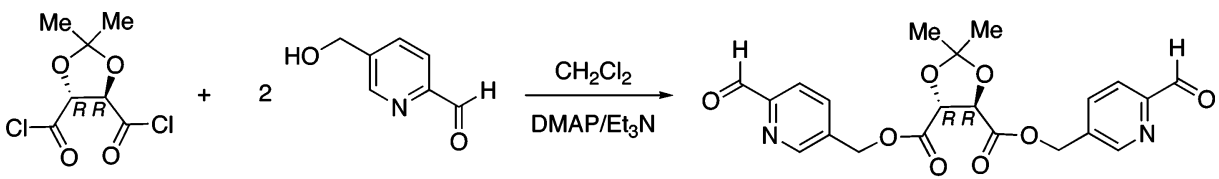

$(R, R)-2$

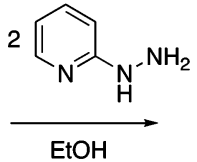

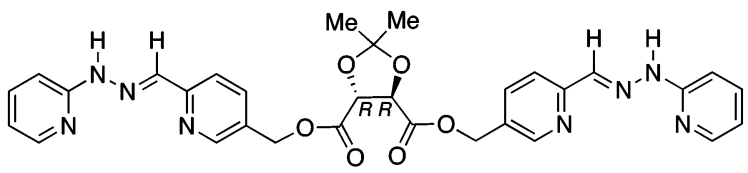

$(R, R)-1$
$( \pm)-\left[\mathrm{M}(\mathrm{PAPHY})_{2}\right] \mathrm{X}_{2} \cdot{ }^{5,6} \mathrm{~A}$ characteristic of the cations in these complexes is the ready deprotonation of the hydrazone$\mathrm{NH}$ groups in the coordinated ligands to give intensely colored, neutral, complexes of the type $( \pm)-\left[\mathrm{M}(\mathrm{PAPY})_{2}\right]$, where PAPY represents the anionic deprotonated form of the neutral PAPHY ligand. The neutral complexes are soluble in most of the usual organic solvents, a property that has been used to extract them (and hence the metals) from aqueous solutions and that has been exploited for analytical procedures and for the use of the complexes as acid-base indicators $^{7}$ and reservoir sensors. ${ }^{8}$

Here we report the results of our work concerning the asymmetric synthesis of two-bladed propeller, octahedral complexes of the type $( \pm)-\left[\mathrm{Fe}(\mathrm{PAPHY})_{2}\right] \mathrm{X}_{2}$ and $( \pm)-[\mathrm{Fe}-$ $\left.(\mathrm{PAPY})_{2}\right]$ by the chiral auxiliary-directed methodology and follow our recent work on the asymmetric transformation of a cationic, double-stranded, dicopper(I) helicate containing achiral bis(bidentate) Schiff bases in the presence of $\Delta$-(-)-tris(catecholato)arsenate $(\mathrm{V}){ }^{9}$

\section{Results and Discussion}

Stereochemical Considerations. The configurations of chiral cations of the type $( \pm)-\left[\mathrm{M}(\mathrm{PAPHY})_{2}\right]^{2+}$ can be assigned by viewing the molecules as helices down their principal $C_{2}$ axes, which bisect the terminal $\mathrm{N}-\mathrm{M}-\mathrm{N}$ angles (Figure 1a). The twists of the ligand blades when viewed down this axis (from either direction) give the actual twist or helicity of the two-bladed propeller complex; a clockwise twist is assigned the $P$ (plus) configuration and the anticlockwise twist the $M$ (minus) configuration. ${ }^{10}$ The $P$ and $M$ descriptors obtained by application of the helix nomenclature, however, have a negative correlation with the

(2) Weizman, H.; Libman, J.; Shanzer, A. J. Am. Chem. Soc. 1998, 120, 2188-2189.

(3) Annunziata, R.; Benaglia, M.; Cinquini, M.; Cozzi, F.; Woods, C. R. Siegel, J. S. Eur. J. Org. Chem. 2001, 173-180.

(4) Mizuno, T.; Takeuchi, M.; Hamachi, I.; Nakashima, K.; Shinkai, S. J. Chem. Soc., Perkin Trans. 2 1998, 2281-2288.

(5) Lions, F.; Martin, K. V. J. Am. Chem. Soc. 1958, 80, 3858-3865. Geldard, J. F.; Lions, F. J. Am. Chem. Soc. 1962, 84, 2262-2263.

(6) Geldard, J. F.; Lions, F. Inorg. Chem. 1963, 2, 270-282.

(7) Cameron, A. J.; Gibson, N. A. Anal. Chim. Acta 1970, 51, 249-256.

(8) Montes, R.; Laserna, J. J. Anal. Sci. 1991, 7, 467-761.

(9) Habermehl, N. C.; Angus, P. M.; Kilah, N. L.; Norén, L.; Rae, A. D.; Willis, A. C.; Wild, S. B. Inorg. Chem. 2006, 45, 1445-1462.

(10) Piguet, C.; Bernardinelli, G.; Hopfgartner, G. Chem. Rev. 1997, 97, 2005-2062.

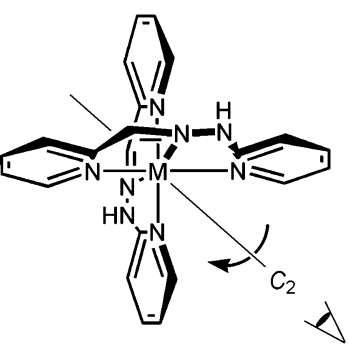

$M$

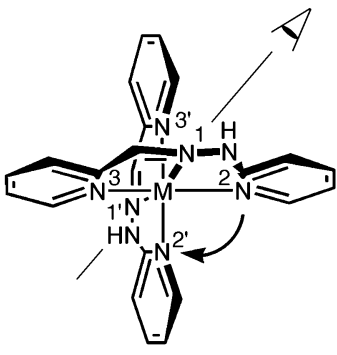

$(O C-6-1 ' 3-C)$

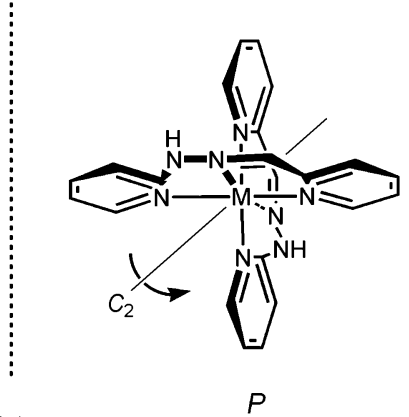

(a)

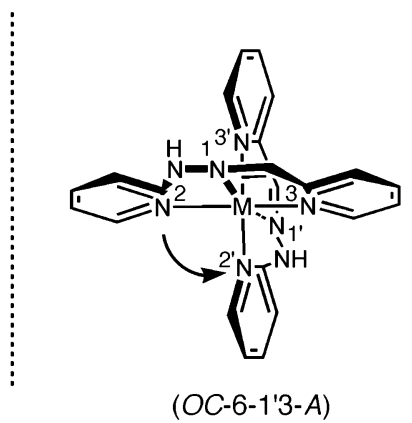

(b)
Figure 1. Configurational descriptors for enantiomers of $( \pm)-[\mathrm{M}(\mathrm{PA}-$ $\left.\mathrm{PHY})_{2}\right]^{2+}$ : (a) helix nomenclature $M$ and $P$; (b) stereochemical descriptors $\left(O C-6-1^{\prime} 3-C\right)$ and $\left(O C-6-1^{\prime} 3-A\right)$.

chirality symbols $A$ (anticlockwise) and $C$ (clockwise) within the configuration indices obtained for octahedral bis(tridentate)metal complexes with use of the IUPAC convention where the molecules are viewed down the principal axis (which contains the ligand of the highest Cahn-IngoldPrelog (CIP) priority1) and noting the direction of the priority sequence for the four ligating atoms in the square plane, orthogonal to the principal axis (Figure 1b). ${ }^{11,12}$

Ligand Syntheses. The Schiff bases PAPHY and 6-MePAPHY were prepared by the literature methods. ${ }^{6}$ The 5-methyl- and 5-hydroxymethyl-substituted ligands 5-MePAPHY and $5-\mathrm{HOCH}_{2} \mathrm{PAPHY}$ were also prepared by the condensation of the appropriate aldehydes with pyridine-2hydrazine. The $C_{2}$ hexadentate $(R, R)-\mathbf{1}$ was synthesized as

(11) Cahn, R. S.; Ingold, C.; Prelog, V. Angew. Chem., Int. Ed. Engl. 1966 5, 385-415. Prelog, V.; Helmchen, G. Angew. Chem., Int. Ed. Engl. 1982, 21, 567-583.

(12) Nomenclature of Inorganic Chemistry (IUPAC Recommendation 2005); Royal Society of Chemistry: Cambridge, 2005; pp 189-190. 


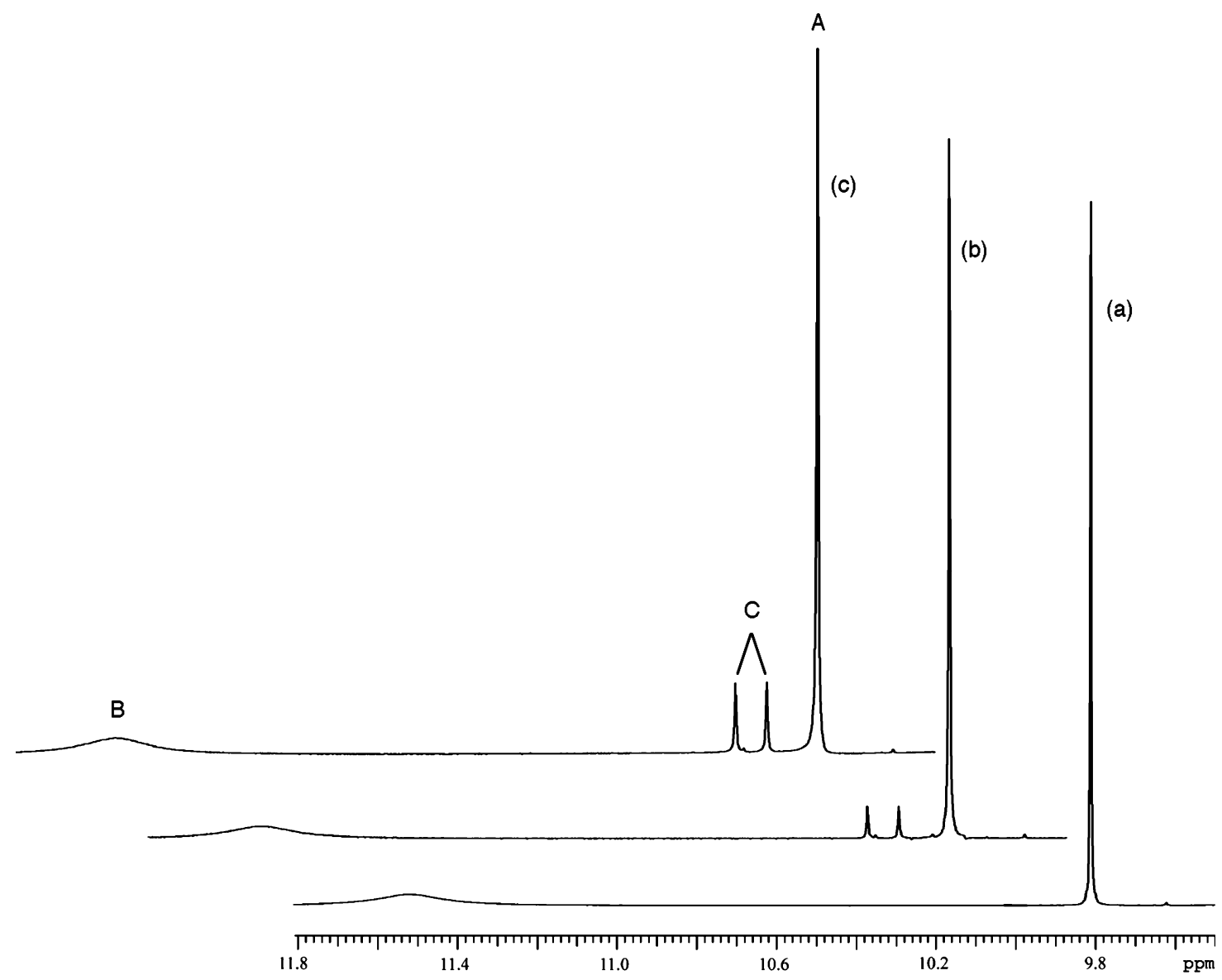

Figure 2. ${ }^{1} \mathrm{H}$ NMR spectra $\left(500 \mathrm{MHz}\right.$, acetone- $\left.d_{6}, 25^{\circ} \mathrm{C}\right)$ of $( \pm)-\left[\mathrm{Fe}(\mathrm{PAPHY})_{2}\right]\left(\mathrm{PF}_{6}\right)_{2}(\mathbf{A})$ and $( \pm)-\left[\mathrm{Fe}(6-\mathrm{MePAPHY})_{2}\right]\left(\mathrm{PF}_{6}\right)_{2}(\mathbf{B})$ showing ligand crossover product $( \pm)-[\mathrm{Fe}(\mathrm{PAPHY})(6-\mathrm{MePAPHY})]\left(\mathrm{PF}_{6}\right)_{2}$ (C) at (a) $5 \mathrm{~min}$, (b) $30 \mathrm{~h}$, and (c) $70 \mathrm{~h}$.

shown in Scheme 1 and was isolated as pale yellow microcrystals having mp $190-201{ }^{\circ} \mathrm{C},[\alpha]_{\mathrm{D}}^{18}=-26.7(c$ $1.1, \mathrm{DMSO})$. The diacid chloride $(R, R)-2$ was synthesized in two steps by the literature procedure. ${ }^{13}$ The intermediate, 5-(hydroxymethyl)pyridine-2-aldehyde (3), was prepared from 2,5-pyridinedimethanol in modest yield $(54 \%)$ by the literature procedure. ${ }^{14}$ Condensation of $(R, R)-2$ with 2.2 equiv of $\mathbf{3}$ in the presence of triethylamine and 4-(dimethylamino)pyridine (DMAP) in dichloromethane gave the dialdehyde $(R, R)-\mathbf{4}$ as a colorless solid in $64 \%$ yield after column chromatography (Scheme 1$)$. Condensation of $(R, R)-4$ with 2.3 equiv of pyridine-2-hydrazine in ethanol furnished the bis(hydrazone) $(R, R)-\mathbf{1}$ as yellow microcrystals. Yield: $80 \%$.

Iron(II) Complexes. Configurational Stability. The configurational stability of the chiral iron(II) stereocenter in complexes of the type $( \pm)-\left[\mathrm{Fe}(\mathrm{PAPHY})_{2}\right] \mathrm{X}_{2}$ and the deprotonated complexes $( \pm)-\left[\mathrm{Fe}(\mathrm{PAPY})_{2}\right]$ was investigated by examining the ${ }^{1} \mathrm{H}$ NMR spectra of pairs of closely related complexes, where the appearance of resonances in the spectra for the corresponding crossover complexes would indicate intermolecular ligand exchange and loss of configurational integrity at iron (Scheme 2). In order for these experiments to be conducted, however, pairs of soluble complexes were

(13) Arnaud, N.; Picard, C.; Cazaux, L.; Tisnès, P. Tetrahedron 1997, 53, 13757-13768.

(14) Dawson, M. I.; Chan, R.; Hobbs, P. D.; Chao, W.; Schiff, L. J. J. Med. Chem. 1983, 26, 1282-1293.

\section{Scheme 2}

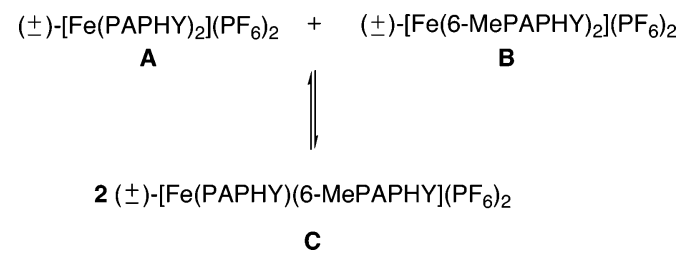

required that exhibited in their ${ }^{1} \mathrm{H}$ NMR spectra, sharp and well-separated resonances for the diagnostic azomethine- $H$ atoms in the protonated and neutral crossover complexes. These considerations eliminated from the investigation complexes derived from 5-methyl- and 5- $\mathrm{HOCH}_{2} \mathrm{PAPHY}$. Thus, $( \pm)-\left[\mathrm{Fe}(\mathrm{PAPHY})_{2}\right]\left(\mathrm{PF}_{6}\right)_{2}(\mathbf{A})$ and $( \pm)-\left[\mathrm{Fe}(6-\mathrm{MePAPHY})_{2}\right]-$ $\left(\mathrm{PF}_{6}\right)_{2}(\mathrm{~B})$ were prepared and equimolar solutions of the two complexes in acetone- $d_{6}$ mixed together at $25{ }^{\circ} \mathrm{C}$ : the ${ }^{1} \mathrm{H}$ NMR spectra were recorded after $5 \mathrm{~min}, 30 \mathrm{~h}$, and $70 \mathrm{~h}$. The spectra in the azomethine- $H$ region are shown in Figure 2. The azomethine- $H$ resonances for $\mathbf{A}$ and $\mathbf{B}$ occur at 9.81 and $11.52 \mathrm{ppm}$, respectively; the broad, downfield peak for the azomethine- $H$ protons in $\mathbf{B}$ is consistent with the small degree of paramagnetism observed for the complex in acetone, viz $0.38 \mu_{\mathrm{B}}$ at $25{ }^{\circ} \mathrm{C}$ (Evans method ${ }^{15}$ ). The literature value for the magnetic moment of the corresponding perchlorate salt in the solid state is $0.9 \mu_{\mathrm{B}}$ at $20{ }^{\circ} \mathrm{C} .{ }^{6} \mathrm{In}$

(15) Evans, D. F. J. Chem. Soc. 1959, 2003-2005. Evans, D. F.; James, T. A. J. Chem. Soc., Dalton Trans. 1979, 723-726. Toftlund, H. Coord. Chem. Rev. 1989, 94, 67-108. 
Scheme 3

$(R, R)-1$
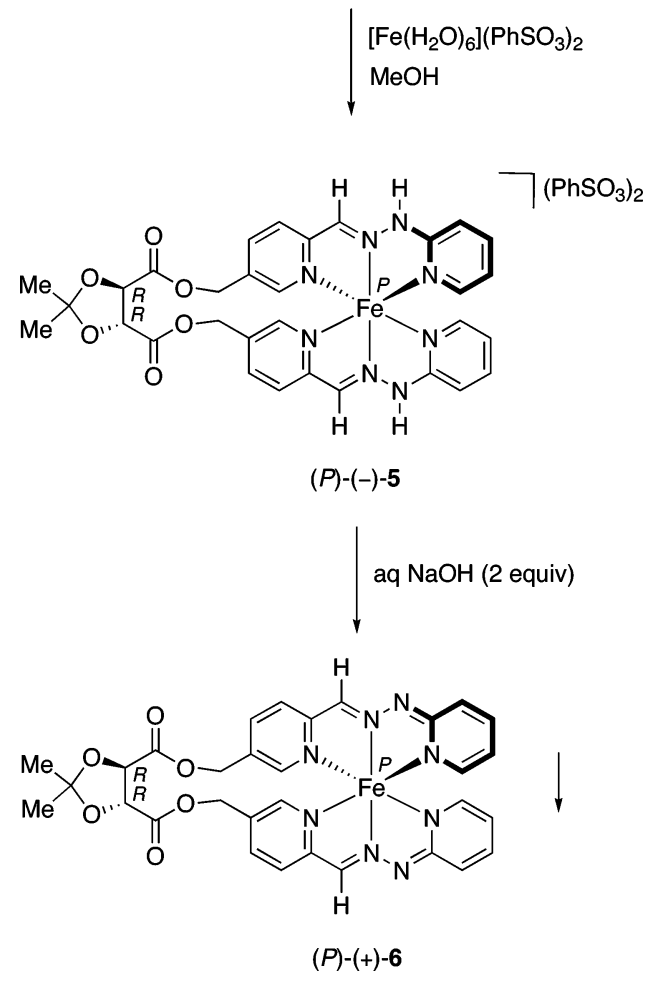

$2,2^{\prime}: 6,6^{\prime \prime}$-terpyridine (tpy) complexes of the type [Fe(tpy) $\left.)_{2}\right]$ $\mathrm{X}_{2}$, substituents in the 6 and $6^{\prime}$ positions of the pyridine rings, which are adjacent to the nitrogen atoms in these rings and weaken the $\mathrm{Fe}-\mathrm{N}$ bonds, favor the high-spin forms of the complexes. ${ }^{16}$ On the basis of the NMR data, it was estimated that the half-life for intermolecular ligand exchange for the system $\mathbf{A}+\mathbf{B} \rightleftarrows \mathbf{2} \mathbf{C}$ in acetone- $d_{6}$ is $200 \mathrm{~h}$ at $25^{\circ} \mathbf{C}$. Ligand exchange between the deprotonated forms of $\mathbf{A}$ and B was not discernible within this period under similar conditions.

Diastereoselective Synthesis. The complex $\left(P_{\mathrm{Fe}}\right)-(-)-[\mathrm{Fe}-$ $\{(R, R)-\mathbf{1}\}]\left(\mathrm{PhSO}_{3}\right)_{2},\left(P_{\mathrm{Fe}}\right)-(-)-\mathbf{5}$, was prepared by the addition of a methanol solution of hexaaquairon(II) benzenesulfonate to a suspension of an equimolar quantity of $(R, R)-\mathbf{1}$ in the same solvent (Scheme 3). Upon the addition of the iron(II) salt, the reaction mixture turned vibrant red. The solution was stirred for $2 \mathrm{~h}$ at room temperature; the product was isolated from the solution by evaporation of the solvent. The high-resolution electrospray mass spectrum of the crude product indicated the exclusive formation of the 1:1 metalto-ligand complex $\left(P_{\mathrm{Fe}}\right)-(-)-5\left(\mathrm{~m} / \mathrm{z}=665.16[\mathrm{M}-\mathrm{H}]^{+}\right)$. The complex crystallized from $95 \%$ methanol-diethyl ether as dark red prisms having $\mathrm{mp}=227-230{ }^{\circ} \mathrm{C}$ and $[\alpha]_{\mathrm{D}}^{18}=$ -838 ( $c 0.014, \mathrm{MeOH})$. The addition of 2 equiv of $10 \%$ aqueous sodium hydroxide to an aqueous solution of $\left(P_{\mathrm{Fe}}\right)$ (-)-5 generated the corresponding dark brown, neutral, deprotonated complex $\left(P_{\mathrm{Fe}}\right)-(+)-[\mathrm{Fe}((R, R)-\mathbf{1}-2 \mathrm{H})],\left(P_{\mathrm{Fe}}\right)-(+)-$

(16) Constable, E. C.; Baum, G.; Bill, E.; Dyson, R.; van Eldik, R.; Fenske, D.; Kaderli, S.; Morris, D.; Neubrand, A.; Neuburger, M.; Smith, D. R.; Wieghardt, K.; Zehnder, M.; Zuberbühler, A. D. Chem. Eur. J. 1999, 5, 498-508
6, which was extracted into dichloromethane. The pure complex was obtained as a dark brown powder by the addition of $n$-hexane to the dichloromethane extract. Yield: $>95 \%$; mp > $250{ }^{\circ} \mathrm{C} ;[\alpha]_{\mathrm{D}}^{18}=+1474(c 0.026, \mathrm{MeOH})$. Both forms of the complex are air-stable solids.

${ }^{1} \mathrm{H}$ NMR Spectroscopy. The ${ }^{1} \mathrm{H}$ and ${ }^{13} \mathrm{C}\left\{{ }^{1} \mathrm{H}\right\}$ NMR spectra of $(R, R)-\mathbf{1}$ and $\left(P_{\mathrm{Fe}}\right)-(-)-\mathbf{5}$ were recorded in chloroform- $d$ and methanol- $d_{4}$ at $25{ }^{\circ} \mathrm{C}$, respectively. Upon complexation of iron(II), the diagnostic azomethine- $H$ resonance for the ligand at $7.92 \mathrm{ppm}$ shift downfield by ca. 1.6 ppm (Figure 3). The diastereotopic $\beta$-picolyl- $\mathrm{CH}_{2}$ protons in $(R, R)-\mathbf{1}$ resonate as an $\mathrm{AB}$ spin system centered at 5.30 and $5.36 \mathrm{ppm}$, but at 4.70 and $5.21 \mathrm{ppm}$ in the protonated complex and at 3.34 and $4.50 \mathrm{ppm}$ in the deprotonated complex. The spectra of $\left(P_{\mathrm{Fe}}\right)-(-)-5$ and $\left(P_{\mathrm{Fe}}\right)-(+)-6$ are consistent with the formation of a single diastereomer of the complex in each case ( $>99 \%$ diastereoselectivity).

Circular Dichroism Spectra. The CD spectra of $\left(P_{\mathrm{Fe}}\right)-$ $(-)-5$ and $\left(P_{\mathrm{Fe}}\right)-(+)-6$ in methanol at $18{ }^{\circ} \mathrm{C}$ are shown in Figure 4. In the visible region, $\Delta \epsilon$ has highest magnitude of ca. 24 and $33 \mathrm{M}^{-1} \mathrm{~cm}^{-1}$ for $\left(P_{\mathrm{Fe}}\right)-(-)-5$ and $\left(P_{\mathrm{Fe}}\right)-(+)-6$, respectively; the peaks are associated with the absorption maxima for the metal-to-ligand charge transfer (MLCT) transitions in the complexes at 380 and $480 \mathrm{~nm}$. Cotton effects observed at shorter wavelengths for the complexes are associated with the chiral auxiliary and are not shown in the figure. The free ligand shows no absorptions in the MLCT region.

Crystal and Molecular Structure of $\left(P_{\mathrm{Fe}}\right)-(-)-5 \cdot 2 \mathrm{CH}_{3} \mathrm{OH} \cdot$ $\mathbf{3} \mathrm{H}_{2} \mathrm{O}$. The solvate $\left(P_{\mathrm{Fe}}\right)-(-)-\mathbf{5} \cdot 2 \mathrm{CH}_{3} \mathrm{OH} \cdot 3 \mathrm{H}_{2} \mathrm{O}$ crystallized as dark red needles following the slow diffusion of diethyl ether into a concentrated solution of the crude complex in 95\% aqueous methanol. The solvate crystallizes in the monoclinic space group $P 2_{1}$ with one chiral cation, two anions and five solvent molecules in the crystallographic asymmetric unit (Table 1). There is disorder in the chiral auxiliary region of the ligand extending from $\mathrm{O} 217$ (O2171) to and including the five-membered dioxolane ring. Interatomic bond lengths and angles around the iron(II) stereocenter are given in Table 2. The structures of the two conformers of the configurationally pure cation are depicted in Figure 5.

The two terminal and the two inner pyridine $\mathrm{Fe}-\mathrm{N}$ distances in the cation at 1.974(2) $\AA$ av (terminal) and 1.972(2) $\AA$ av (inner) are similar to those for the terminal $\mathrm{Fe}-\mathrm{N}$ bonds in low-spin $\left[\mathrm{Fe}(\text { tpy })_{2}\right]\left(\mathrm{ClO}_{4}\right)_{2} \cdot 0.5 \mathrm{H}_{2} \mathrm{O}$, viz. $1.988 \AA$ av. ${ }^{17}$ The central hydrazone $\mathrm{Fe}-\mathrm{N}$ distances of $1.885(2)$ and 1.873(2) $\AA$ in the cation are also similar to those in the tpy complex, viz. $1.889 \AA$ av. Each of the PAPHY groups in the complex is essentially planar, with the substituted pyridine rings at the auxiliary end of the ligand being bent slightly toward one another. This deviation from strictly octahedral coordination is reflected in the bite angle of 86.47 $(9)^{\circ}$ for $\mathrm{N} 115-\mathrm{Fe}-\mathrm{N} 215$ and the $\mathrm{N}-\mathrm{Fe}-\mathrm{N}$ angles between

(17) Baker, A. T.; Goodwin, H. A. Aust. J Chem. 1985, 38, 207-220. Oshio, H.; Spiering, H.; Ksenofontov, V.; Renz, F.; Gütlich, P. Inorg. Chem. 2001, 40, 1143-1150. 
Warr et al.

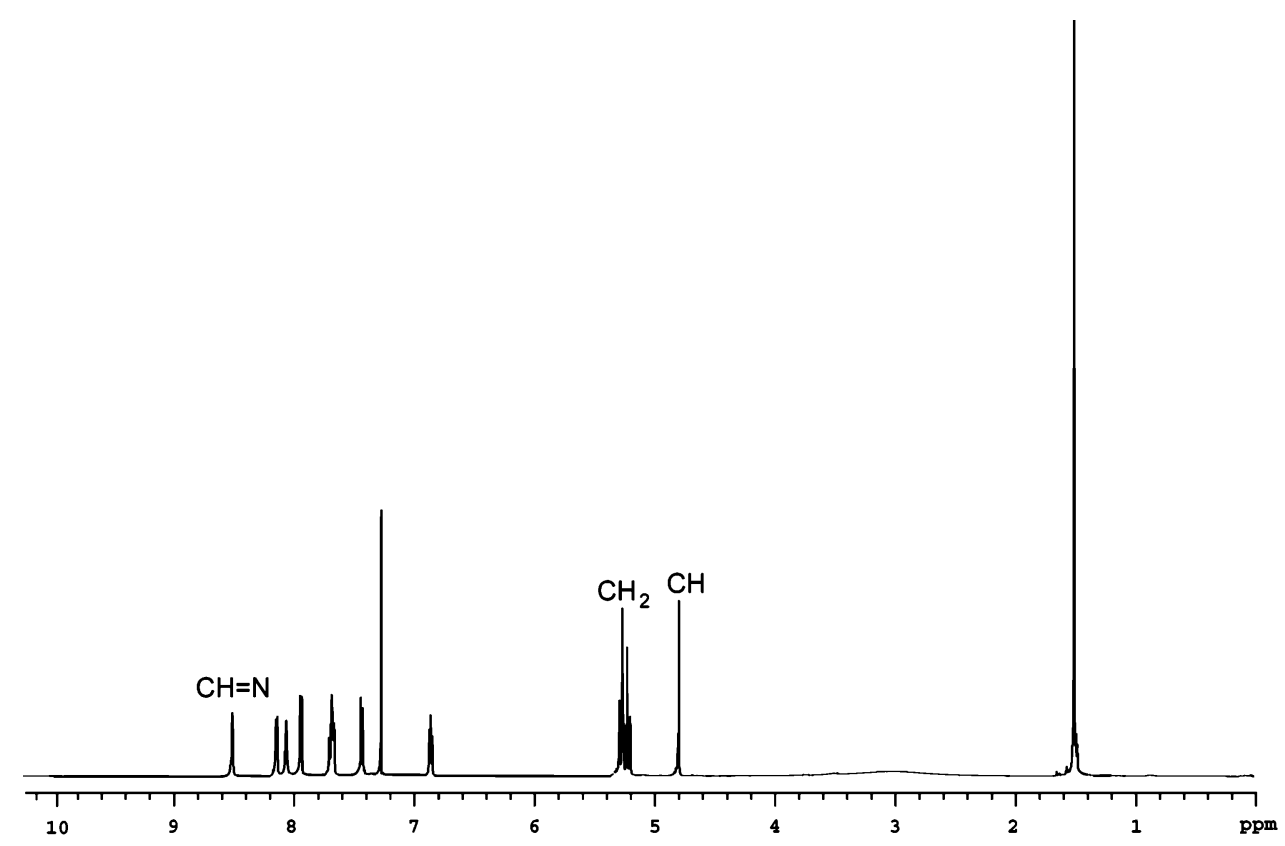

(a)

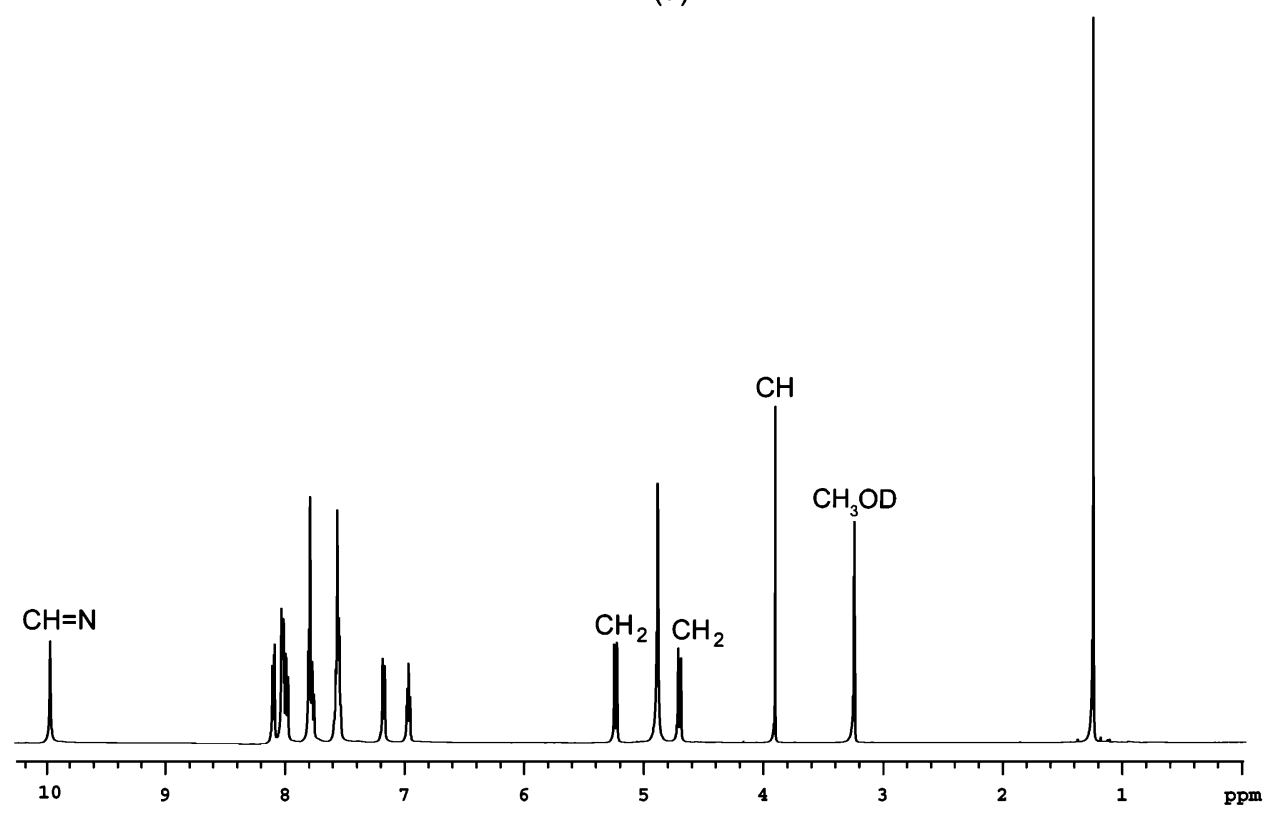

(b)

Figure 3. ${ }^{1} \mathrm{H}$ NMR spectra $\left(500 \mathrm{MHz}, 25^{\circ} \mathrm{C}\right)$ : (a) $(R, R)-\mathbf{1}\left(\mathrm{CDCl}_{3}\right)$; (b) $\left(P_{\mathrm{Fe}}\right)-(-)-\mathbf{5}\left(\mathrm{CD}_{3} \mathrm{OD}\right)$.

opposite vertexes, which are $161.45(8)^{\circ}$ and $161.40(9)^{\circ}$ (for the terminal and inner end pairs) and $177.04(11)^{\circ}$ (for the central pair). The major conformer of the cation $(60 \%)$, Figure 5a, has overall $C_{1}$ symmetry with the ester-carbonyl- $O$ atoms $\mathrm{O} 119$ and $\mathrm{O} 219$ having a cis disposition; in the minor conformer of the cation (40\%), Figure 5b, the corresponding oxygen atoms $\mathrm{O} 119$ and $\mathrm{O} 2191$ have a trans relationship in which the overall symmetry of the cation is $C_{2}$. A view indicating the absolute configurations of the three chiral stereocenters in the minor conformer of the configurationally pure cation of $C_{2}$ symmetry and emphasizing the two-bladed propeller structure of the iron(II) stereocenter is given in Figure 6.
Removal of the Chiral Auxiliary. Removal of the chiral auxiliary from the complex was achieved by saponification (Scheme 4). Thus, an aqueous solution of $\left(P_{\mathrm{Fe}}\right)-(-)-5$ was treated with 4 equiv of $10 \%$ aqueous sodium hydroxide. The solution instantaneously turned dark brown-black, and a fine solid separated over $30 \mathrm{~min}$. The dark brown-black precipitate was insoluble in most solvents, but spectroscopic data were obtained in methanol- $d_{4}$ and DMSO- $d_{6}$. The structure of $\left(P_{\mathrm{Fe}}\right)-(+)-\left[\mathrm{Fe}\left(5-\mathrm{HOCH}_{2} \mathrm{PAPY}\right)_{2}\right],\left(P_{\mathrm{Fe}}\right)-(+)-7$, was confirmed by ${ }^{1} \mathrm{H}$ NMR spectroscopy in methanol- $d_{4}$ : the spectrum of the complex was identical to that of the corresponding racemate $( \pm)-7$, which had been independently characterized. Analytical and mass spectral data for the 


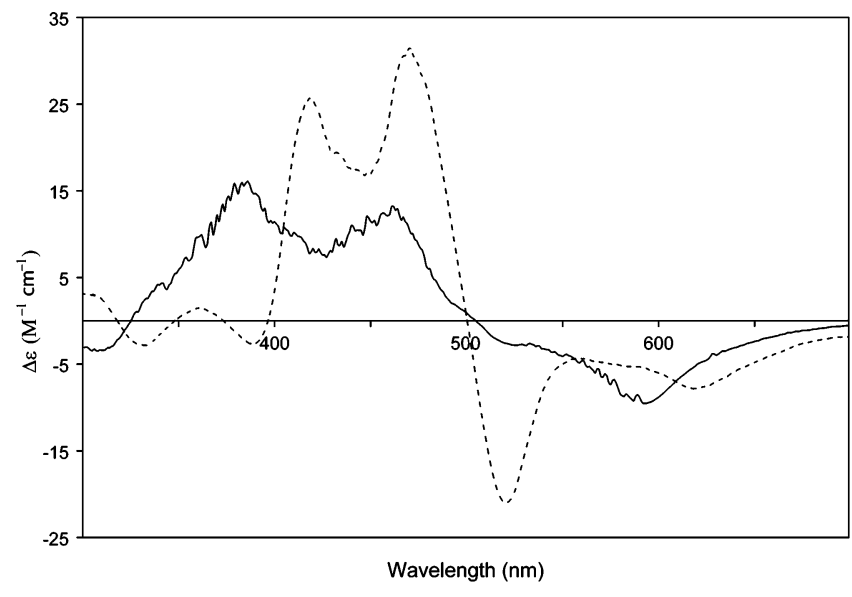

Figure 4. $\mathrm{CD}$ spectra of $\left(P_{\mathrm{Fe}}\right)-(-)-5(-)$ and $\left(P_{\mathrm{Fe}}\right)-(+)-6(---)$ in methanol at $18{ }^{\circ} \mathrm{C}$.

Table 1. Crystallographic Data and Experimental Parameters for the $\mathrm{X}$-ray Crystal Structure Analysis of $\left(P_{\mathrm{Fe}}\right)-(-)-\mathbf{5} \cdot 2 \mathrm{CH}_{3} \mathrm{OH} \cdot 3 \mathrm{H}_{2} \mathrm{O}$

\begin{tabular}{|c|c|}
\hline formula & $\mathrm{C}_{45} \mathrm{H}_{54} \mathrm{FeN}_{8} \mathrm{O}_{17} \mathrm{~S}_{2}$ \\
\hline $\mathrm{fw}, \mathrm{g} \mathrm{mol}^{-1}$ & 1098.95 \\
\hline cryst color, habit & red, prism \\
\hline cryst size, $\mathrm{mm}^{3}$ & $0.29 \times 0.17 \times 0.16$ \\
\hline space group & $P 2_{1}$ \\
\hline cryst syst & monoclinic \\
\hline$a, \AA$ & $9.1842(1)$ \\
\hline$b, \AA$ & $19.8044(3)$ \\
\hline$c, \AA$ & $14.2977(2)$ \\
\hline$\beta, \mathrm{deg}$ & $101.8508(10)$ \\
\hline$V, \AA^{3}$ & $2545.14(6)$ \\
\hline Z & 2 \\
\hline$d_{\text {calcd }}, \mathrm{g} \mathrm{cm}^{-3}$ & 1.434 \\
\hline$\mu, \mathrm{cm}^{-1}$ & 4.57 \\
\hline instrument & Nonius Kappa CCD \\
\hline radiation & Mo K $\alpha$ \\
\hline no. unique reflens & 11626 \\
\hline no. reflens obsd & $8221(I>3.00 \sigma(I))$ \\
\hline $2 \theta$ range, deg & $5-55$ \\
\hline scan technique & $\varphi$ and $\omega$ scans with CCD \\
\hline temp, $\mathrm{K}$ & 200 \\
\hline struct refinement & CRYSTALS $^{22} / \mathrm{maXus}^{23}$ \\
\hline final $R, R_{\mathrm{W}}$ & $0.0341,0.0401$ \\
\hline
\end{tabular}

Table 2. Selected Bond Distances $(\AA)$ and Angles (deg) for the Cation of $\left(P_{\mathrm{Fe}}\right)-(-)-5 \cdot 2 \mathrm{CH}_{3} \mathrm{OH} \cdot 3 \mathrm{H}_{2} \mathrm{O}$

\begin{tabular}{lrlc}
\hline $\mathrm{Fe}-\mathrm{N} 101$ & $1.974(2)$ & $\mathrm{Fe}-\mathrm{N} 201$ & $1.973(2)$ \\
$\mathrm{Fe}-\mathrm{N} 108$ & $1.885(2)$ & $\mathrm{Fe}-\mathrm{N} 208$ & $1.873(2)$ \\
$\mathrm{Fe}-\mathrm{N} 115$ & $1.970(2)$ & $\mathrm{Fe}-\mathrm{N} 215$ & $1.974(2)$ \\
$\mathrm{N} 101-\mathrm{Fe}-\mathrm{N} 108$ & $81.26(9)$ & $\mathrm{N} 108-\mathrm{Fe}-\mathrm{N} 215$ & $102.14(10)$ \\
$\mathrm{N} 101-\mathrm{Fe}-\mathrm{N} 115$ & $161.45(8)$ & $\mathrm{N} 115-\mathrm{Fe}-\mathrm{N} 201$ & $92.64(8)$ \\
$\mathrm{N} 101-\mathrm{Fe}-\mathrm{N} 201$ & $93.56(9)$ & $\mathrm{N} 115-\mathrm{Fe}-\mathrm{N} 208$ & $100.42(9)$ \\
$\mathrm{N} 101-\mathrm{Fe}-\mathrm{N} 208$ & $97.79(9)$ & $\mathrm{N} 115-\mathrm{Fe}-\mathrm{N} 215$ & $86.47(9)$ \\
$\mathrm{N} 101-\mathrm{Fe}-\mathrm{N} 215$ & $93.08(9)$ & $\mathrm{N} 201-\mathrm{Fe}-\mathrm{N} 208$ & $81.20(10)$ \\
$\mathrm{N} 108-\mathrm{Fe}-\mathrm{N} 115$ & $80.72(9)$ & $\mathrm{N} 201-\mathrm{Fe}-\mathrm{N} 215$ & $161.40(9)$ \\
$\mathrm{N} 108-\mathrm{Fe}-\mathrm{N} 201$ & $96.04(10)$ & $\mathrm{N} 208-\mathrm{Fe}-\mathrm{N} 215$ & $80.69(10)$ \\
$\mathrm{N} 108-\mathrm{Fe}-\mathrm{N} 208$ & $177.04(11)$ & &
\end{tabular}

complex were also consistent with the formulation $[\mathrm{Fe}(5-$ $\left.\mathrm{HOCH}_{2} \mathrm{PAPY}\right)_{2}$.

Determination of Enantiomeric Purity. Conventional methods for determining enantiomeric purity failed because of the poor solubility of $\left(P_{\mathrm{Fe}}\right)-(+)-7$ in appropriate solvents. Thus, the attempted use of $\mathrm{CD}$ spectroscopy and the lanthanide shift reagent $\mathrm{Eu}(\mathrm{hfa})_{3}$, the chiral ion-pairing agent TRISPHAT, ${ }^{18}$ and the derivatization of the deprotonated complex with chiral alkylating agents were unsuccessful. The reprotonation of the $\left(P_{\mathrm{Fe}}\right)-(+)-7$ with 1.5 equiv $(\mathrm{a} R)$ -

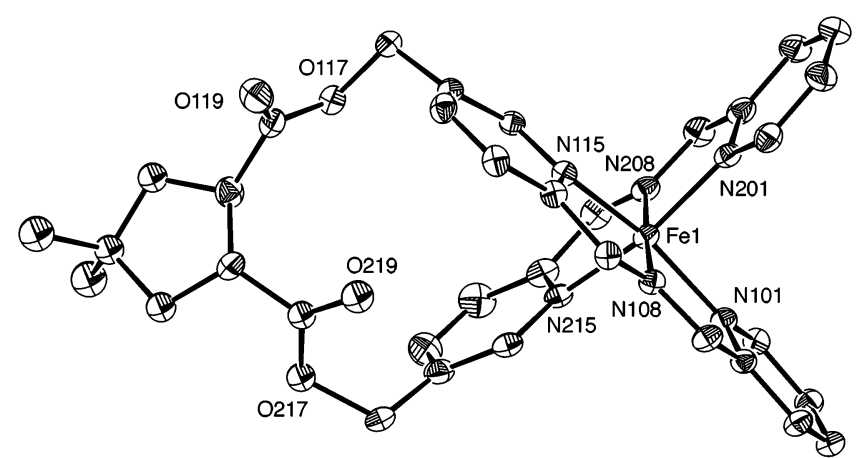

(a)

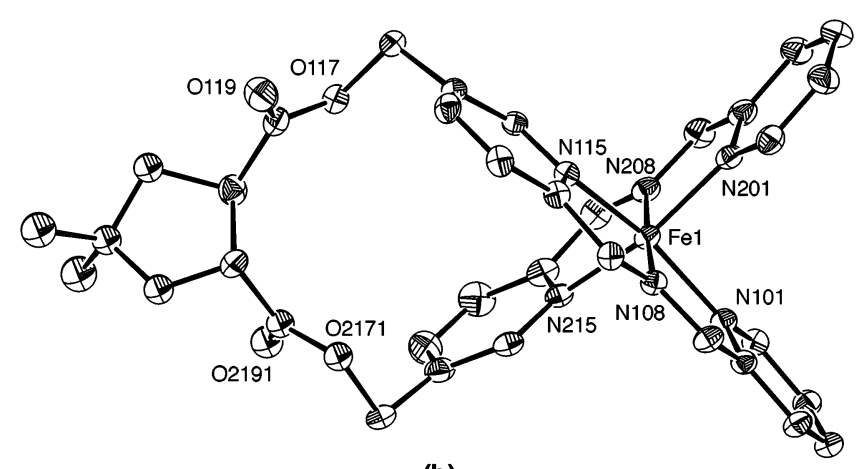

(b)

Figure 5. Molecular structure of the major (a) and minor (b) conformers of the cation of $\left(P_{\mathrm{Fe}}\right)-(-)-\mathbf{5} \cdot 2 \mathrm{CH}_{3} \mathrm{OH} \cdot 3 \mathrm{H}_{2} \mathrm{O}(30 \%$ probability ellipsoids shown for non-hydrogen atoms).

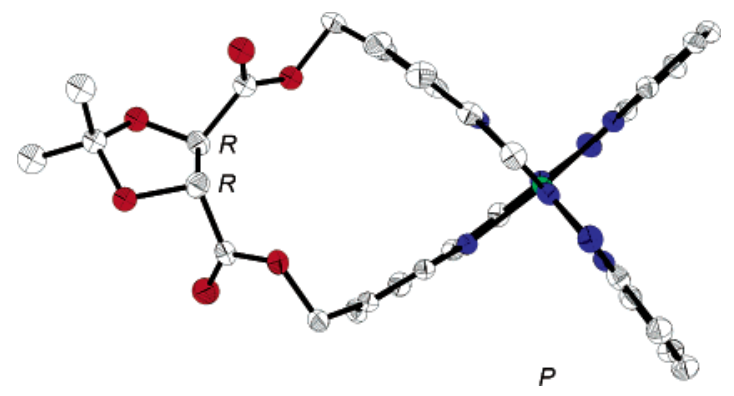

Figure 6. Molecular structure of the minor conformer of the cation of $\left(P_{\mathrm{Fe}}\right)-(-)-5 \cdot 2 \mathrm{CH}_{3} \mathrm{OH} \cdot 3 \mathrm{H}_{2} \mathrm{O}$ indicating absolute configurations of chiral centers and emphasizing the two-bladed propeller structure of the iron(II) stereocenter (30\% probability ellipsoids shown for non-hydrogen atoms).

\section{Scheme 4}

$$
\begin{aligned}
& \left(P_{\mathrm{Fe}}\right)-(-)-5 \\
& \quad \text { aq } \mathrm{NaOH} \text { (4 equiv) }
\end{aligned}
$$

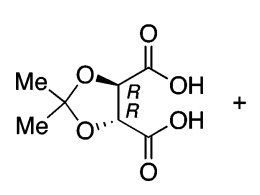

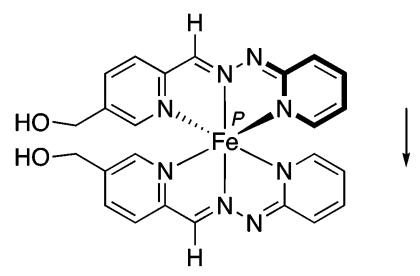

$\left(P_{\mathrm{Fe}}\right)-(+)-7$

binaphthyl phosphoric acid, $(\mathrm{a} R)-\mathbf{8}$, however, gave a product that exhibited in the ${ }^{1} \mathrm{H}$ NMR spectrum in dichloromethane$d_{2}$ clear splittings of the resonances for the azomethine 


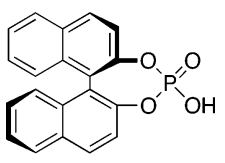

$(\mathrm{a} R)-8$

protons of the equimolar mixture of diastereomeric salts. The addition of $>2$ equiv of $(\mathrm{a} R)-8$ to the complex also gave a solid that was soluble in dichloromethane, but the ${ }^{1} \mathrm{H}$ NMR spectrum of the complex was broad. Thus, the deprotonated form of the racemic complex $( \pm)-7$ was dissolved in the minimum quantity of methanol and 1.5 equiv of solid $(\mathrm{a} R)-8$ was added-the brown solution of the deprotonated complex instantly turned dark red. The solution was stirred for 15 min, and then dichloromethane and water were added. After being stirred for a further $30 \mathrm{~min}$, the organic layer was separated, dried $\left(\mathrm{MgSO}_{4}\right)$, evaporated to dryness, and the ${ }^{1} \mathrm{H}$ NMR spectrum of the residue was recorded (Figure $7 \mathrm{a}$ ). The corresponding spectrum of the optically active complex $\left(P_{\mathrm{Fe}}\right)-(+)-7$ in the presence of 1.5 equiv of $(\mathrm{a} R)-\mathbf{8}$ is shown in Figure $7 b$. Although complete baseline separation was not

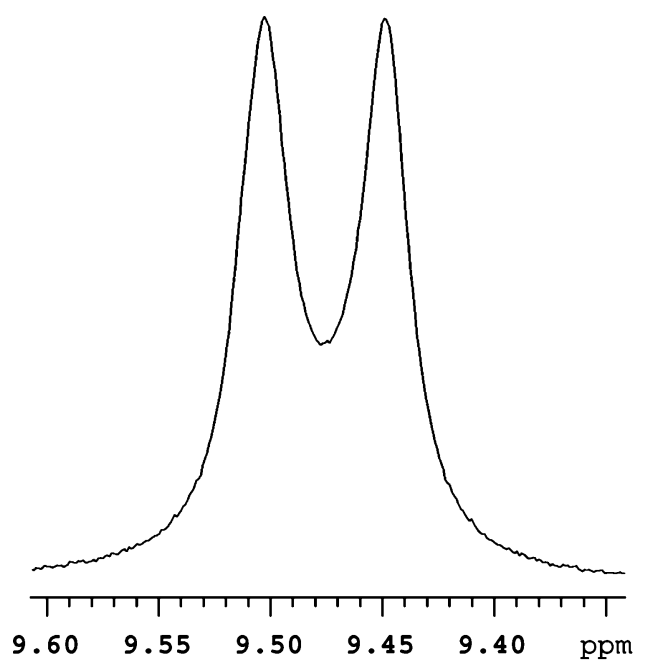

(a)

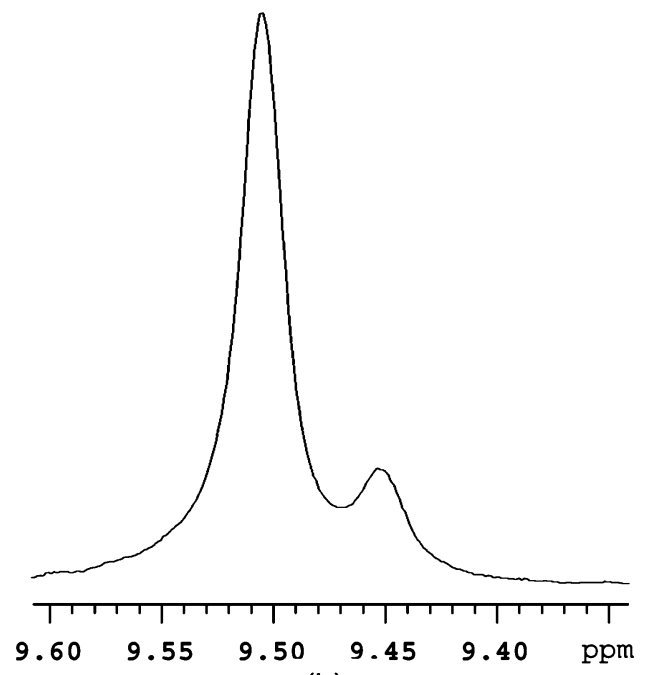

(b)

Figure 7. ${ }^{1} \mathrm{H}$ NMR spectrum $\left(\mathrm{CD}_{2} \mathrm{Cl}_{2}, 500 \mathrm{MHz}, 25{ }^{\circ} \mathrm{C}\right)$ : (a) ( \pm )-[Fe$\left.\left(5-\mathrm{HOCH}_{2} \mathrm{PAPY}\right)_{2}\right]$ in the presence of 1.5 equiv of $(\mathrm{a} R)-8 ;(\mathrm{b})\left(P_{\mathrm{Fe}}\right)-(+)-$ $\left[\mathrm{Fe}\left(5-\mathrm{HOCH}_{2} \mathrm{PAPY}\right)_{2}\right]$ in the presence of 1.5 equiv of $(\mathrm{a} R)-8$. achieved in the spectra, curve-fitting established that the main peak in the spectrum of the optically active complex corresponded to an $85: 15=P_{\mathrm{Fe}} / M_{\mathrm{Fe}}$ mixture of the diastereomeric salts. Since the protonation step is quantitative, as indicated by the observation of equal intensities for the two peaks corresponding to the two diastereomers arising from the protonation of the racemate, and the knowledge that the diastereomer from which the $\left(P_{\mathrm{Fe}}\right)-(+)-7$ was derived by hydrolysis was diastereomerically pure, the racemization observed must have occurred during the saponification step. Optical rotations of a sample of $\left(P_{\mathrm{Fe}}\right)-(+)-7$ obtained from the asymmetric synthesis were measured in methanol over 3 days: no change in the specific rotation was observed over this period. A solution of $\left(P_{\mathrm{Fe}}\right)-(+)-7$ in methanol, however, when treated with a trace of solid sodium hydroxide immediately lost optical activity. It was therefore evident that the apparent loss of enantioselectivity in the asymmetric synthesis was due to racemization during the saponification step.

\section{Conclusion}

The enantiomerically pure ligand $(R, R)-\mathbf{1}$ chelates iron(II) to furnish the complex $\left(P_{\mathrm{Fe}}\right)-(-)-5$ with complete diastereoselectivity. The presence of a single diastereomer of the complex in solution was confirmed by ${ }^{1} \mathrm{H}$ NMR spectroscopy and the configuration at the iron(II) stereocenter $(P)$ by a single crystal X-ray structure determination. Saponification of the chiral auxiliary from configurationally pure $\left(P_{\mathrm{Fe}}\right)-(-)-5$ afforded the deprotonated complex $\left(P_{\mathrm{Fe}}\right)-$ $(+)-7$ in $85 \%$ enantioselectivity. The enantiomeric purity of $\left(P_{\mathrm{Fe}}\right)-(+)-7$ was established by reprotonation with 1.5 equiv of the enantiomerically pure acid $(\mathrm{a} R)-\mathbf{8}$ in dichloromethane$d_{2}$; the appearance in the ${ }^{1} \mathrm{H}$ NMR spectrum of the sample of two, well-defined azomethine- $H$ resonances for the two possible diastereomers of the protonated complex in the ratio $85: 15$ indicated $85 \%$ enantioselectivity for the hydrolysis step. The asymmetric synthesis of $\left(P_{\mathrm{Fe}}\right)-(+)-7$ is the first example of an inorganic asymmetric synthesis using the classical organic methodology of chiral auxiliary-directed, asymmetric synthesis.

\section{Experimental Section}

General Methods. Reactions involving air-sensitive compounds were performed under a positive pressure of nitrogen using Schlenk techniques. Dry, degassed solvents were obtained by distillation over appropriate drying agents. Routine NMR spectra were measured on Varian INOVA spectrometers operating at 300 and $500\left({ }^{1} \mathrm{H}\right)$ and 75 and $125 \mathrm{MHz}\left({ }^{13} \mathrm{C}\left\{{ }^{1} \mathrm{H}\right\}\right)$. Chemical shifts $(\delta)$ are reported in ppm relative to the internal TMS for ${ }^{1} \mathrm{H}$ NMR spectra recorded in chloroform- $d$, or relative to the residual solvent peak for other solvents. For ${ }^{13} \mathrm{C}\left\{\mathrm{H}^{1}\right\}$ NMR spectra, the chemical shifts are reported relative to the solvent peak. Melting points were determined with use of a Reichert hot-stage melting point apparatus. Optical rotations were measured on the specified solutions at 18 ${ }^{\circ} \mathrm{C}$ with a Perkin-Elmer Model 241 polarimeter. Specific rotations are within $\pm 0.05 \mathrm{deg} \mathrm{cm}^{2} \mathrm{~g}^{-1}$. The rotations of the metal complexes

(18) Lacour, J. Chimia 2002, 56, 672-675. Lacour, J.; Hebbe-Viton, V. Chem. Soc. Rev. 2003, 32, 373-382. 
were measured on solutions in 1 or $5 \mathrm{~cm}$ cells at $18{ }^{\circ} \mathrm{C}$ with use of a Jobin Yvon Model CD6 spectrophotometer operating in the ORD mode. Circular dichroism measurements were recorded in methanol on the same instrument. Elemental analyses were performed and mass spectra measured by staff within the Research School of Chemistry. The Schiff base PAPHY, ${ }^{6}(\mathrm{a} R)$-binaphthyl phosphoric acid, ${ }^{19}$ and hexaaquairon(II) benzenesulfonate ${ }^{20}$ were prepared by the literature methods.

2,5-Pyridinedimethanol. This compound was prepared by the literature procedure with the following modifications. ${ }^{21}$ 2,5-Bis(methoxycarbonyl)pyridine $(5.03 \mathrm{~g}, 0.03 \mathrm{~mol})$ was suspended in ethanol $(70 \mathrm{~mL})$, and the mixture was cooled to $0{ }^{\circ} \mathrm{C}$ in an ice bath. Sodium borohydride $(4.53 \mathrm{~g}, 0.12 \mathrm{~mol})$ was added in small portions to the mixture. After the reaction mixture was stirred for $1 \mathrm{~h}$ at $0{ }^{\circ} \mathrm{C}$, the ice bath was removed; the ongoing exothermic reaction caused the solution to warm and boil under reflux. Stirring of the mixture was continued for $3 \mathrm{~h}$, and then it was heated overnight under reflux. The solvent was removed by distillation, and the residue was dissolved in acetone $(70 \mathrm{~mL})$. Saturated aqueous potassium carbonate $(70 \mathrm{~mL})$ was added, and the mixture was heated at boiling temperature for $1 \mathrm{~h}$. This resulted in a yellow layer separating from the reaction mixture, which was isolated and extracted continuously with chloroform (ca. $14 \mathrm{~h}$ ) to yield the product as a yellow oil. Yield: $3.07 \mathrm{~g}(84 \%)$ [lit. ${ }^{21} 79 \%$ ]. ${ }^{1} \mathrm{H}$ NMR $\left(\mathrm{D}_{2} \mathrm{O}, 300 \mathrm{MHz}\right): \delta 4.68\left(\mathrm{~s}, 2 \mathrm{H}, \mathrm{CH}_{2}\right), 4.72\left(\mathrm{~s}, 2 \mathrm{H}, \mathrm{CH}_{2}\right), 7.51$ $\left(\mathrm{d}, 1 \mathrm{H},{ }^{3} J_{\mathrm{HH}}=7.8 \mathrm{~Hz}, \mathrm{py} H\right), 8.43\left(\mathrm{~d}, 1 \mathrm{H},{ }^{3} J_{\mathrm{HH}}=6.1 \mathrm{~Hz}, \mathrm{py} H\right)$, 8.45 (s, $1 \mathrm{H}$, pyH-6).

5-(Hydroxymethyl)pyridine-2-aldehyde (3). This compound was prepared from 2,5-pyridinedimethanol and was isolated as an almost colorless solid by the literature procedure. ${ }^{14}$ Yield: $54 \%$, $\mathrm{mp}=75^{\circ} \mathrm{C}\left[\right.$ lit. $\left.^{14} 75^{\circ} \mathrm{C}\right] .{ }^{1} \mathrm{H}$ NMR $\left(\mathrm{CDCl}_{3}, 300 \mathrm{MHz}\right): \delta 4.88(\mathrm{~s}$, $\left.2 \mathrm{H}, \mathrm{CH}_{2}\right), 7.92\left(\mathrm{t}, 1 \mathrm{H},{ }^{3} J_{\mathrm{HH}}=6.0 \mathrm{~Hz}, \mathrm{py} H\right), 7.98\left(\mathrm{~d}, 2 \mathrm{H},{ }^{3} J_{\mathrm{HH}}\right.$ $=8.0 \mathrm{~Hz}$, py $H$ ), 8.78 (s, $1 \mathrm{H}$, pyH-6), 10.09 (s, $1 \mathrm{H}, \mathrm{CHO}$ ).

5-Methylpyridine-2-aldehyde 2'-Pyridylhydrazone (5-MePAPHY). This compound was prepared by condensation of 5-methylpyridine-2-aldehyde with pyridine-2-hydrazine in a manner similar to that reported for PAPHY; the pure compound crystallized as fine yellow needles from hot ethanol. Yield: $94 \%$; $\mathrm{mp}=169-$ $172{ }^{\circ} \mathrm{C}$. Anal. Calcd for $\mathrm{C}_{12} \mathrm{H}_{12} \mathrm{~N}_{4}$ : C, 67.9; H, 5.7; N, 26.4. Found: C, 67.8; H, 5.8; N, 26.3. ${ }^{1} \mathrm{H}$ NMR $\left(\mathrm{CDCl}_{3}, 300 \mathrm{MHz}\right): \delta$ $2.36\left(\mathrm{~s}, 3 \mathrm{H}, \mathrm{CH}_{3}\right), 6.82\left(\mathrm{t}, 1 \mathrm{H},{ }^{3} J_{\mathrm{HH}}=5.0 \mathrm{~Hz}, \mathrm{py} H\right), 7.41(\mathrm{~d}, 1$ $\mathrm{H},{ }^{3} J_{\mathrm{HH}}=8.7 \mathrm{~Hz}$, py $\left.H\right), 7.52\left(\mathrm{~d}, 1 \mathrm{H},{ }^{3} J_{\mathrm{HH}}=6.4 \mathrm{~Hz}\right.$, py $\left.H\right), 7.64$ $\left(\mathrm{t}, 1 \mathrm{H},{ }^{3} J_{\mathrm{HH}}=6.9 \mathrm{~Hz}, \mathrm{py} H\right), 7.89(\mathrm{~s}, 1 \mathrm{H}, \mathrm{CH}=\mathrm{N}), 7.91(\mathrm{~d}, 1 \mathrm{H}$, py $H), 8.19\left(\mathrm{~d}, 1 \mathrm{H},{ }^{3} J_{\mathrm{HH}}=4.9 \mathrm{~Hz}\right.$, py $\left.H\right), 8.40(\mathrm{~s}, 1 \mathrm{H}$, py $H-6)$, $9.41(\mathrm{~s}, 1 \mathrm{H}, \mathrm{NH})$. LR ESI-MS: $m / z=213.1 \mathrm{amu}(100,[\mathrm{M}+$ $\left.\mathrm{H}]^{+}\right)$.

5-(Hydroxymethyl)pyridine-2-aldehyde 2'-Pyridylhydrazone (5-HOCH 2 PAPHY). This compound was prepared by condensation of 5-(hydroxymethyl)pyridine-2-aldehyde with pyridine-2-hydrazine in a manner similar to that reported for PAPHY; the pure compound crystallized as fine yellow needles from hot ethanol. Yield: $96 \%$; $\mathrm{mp}=195-198{ }^{\circ} \mathrm{C}$. Anal. Calcd for $\mathrm{C}_{12} \mathrm{H}_{12} \mathrm{~N}_{4} \mathrm{O}: \mathrm{C}, 63.2 ; \mathrm{H}, 5.3$; N, 24.6. Found: C, 63.1; H, 5.6; N, 24.3. ${ }^{1} \mathrm{H}$ NMR $\left(\mathrm{CD}_{3} \mathrm{OD}, 300\right.$

(19) Jacques, J.; Fouquey, C. Org. Synth. 1989, 67, 1-12.

(20) Ephraim, F.; Pfister, A. Helv. Chim. Acta 1925, 8, 229-241.

(21) Wörsdörfer, U.; Vögtle, F.; Nieger, M.; Waletzke, M.; Grimme, S.; Glorius, F.; Pfaltz, A. Synthesis 1999, 597-602.

(22) Watkin, D. J.; Prout, C. K.; Carruthers, J. R.; Betteridge, P. W. CRYSTALS Issue 10; Chemical Crystallography Laboratory: Oxford, U.K., 1996.

(23) Mackay, S.; Gilmore, C. J.; Edwards, C.; Stewart, N.; Shankland, K. maXus Computer Program for the Solution and Refinement of Crystal Structures; Nonius: Delft, The Netherlands; MacScience: Japan; and University of Glascow: Glascow, Scotland, 1999.
$\mathrm{MHz}): \delta 4.67\left(\mathrm{~s}, 2 \mathrm{H}, \mathrm{CH} H_{2}\right), 6.85\left(\mathrm{t}, 1 \mathrm{H},{ }^{3} J_{\mathrm{HH}}=6.5 \mathrm{~Hz}, \mathrm{py} H\right)$, $7.35\left(\mathrm{~d}, 1 \mathrm{H},{ }^{3} J_{\mathrm{HH}}=8.5 \mathrm{~Hz}\right.$, pyH$), 7.69\left(\mathrm{t}, 1 \mathrm{H},{ }^{3} J_{\mathrm{HH}}=7.0 \mathrm{~Hz}\right.$, py $H), 7.85\left(\mathrm{~d}, 1 \mathrm{H},{ }^{3} J_{\mathrm{HH}}=8.5 \mathrm{~Hz}, \mathrm{py} H\right), 8.00(\mathrm{~s}, 1 \mathrm{H}, \mathrm{C} H=\mathrm{N})$, $8.08\left(\mathrm{~d}, 1 \mathrm{H},{ }^{3} J_{\mathrm{HH}}=8.0 \mathrm{~Hz}, \mathrm{py} H\right), 8.10\left(\mathrm{t}, 1 \mathrm{H},{ }^{3} J_{\mathrm{HH}}=7.5 \mathrm{~Hz}\right.$, py $H), 8.43$ (s, $1 \mathrm{H}$, py $H-6), 9.41(\mathrm{~s}, 1 \mathrm{H}, \mathrm{N} H)$. LR ESI-MS: $\mathrm{m} / \mathrm{z}=$ $251.0\left(22,[\mathrm{M}+\mathrm{Na}]^{+}\right), 229.0 \mathrm{amu}\left(100,[\mathrm{M}+\mathrm{H}]^{+}\right)$.

6-Methylpyridine-2-aldehyde 2'-Pyridylhydrazone (6-MePAPHY). This compound was prepared from 6-methylpyridine2-aldehyde and pyridine-2-hydrazine by the literature procedure; the pure compound crystallized as a pale yellow powder from the hot ethanol. ${ }^{6}$ Yield: $92 \%$; $\mathrm{mp}=206-208^{\circ} \mathrm{C}$ [lit. $\left.{ }^{6} 208-210{ }^{\circ} \mathrm{C}\right]$. ${ }^{1} \mathrm{H}$ NMR (acetone- $\left.d_{6}, 500 \mathrm{MHz}\right): \delta 2.49\left(\mathrm{~s}, 3 \mathrm{H}, \mathrm{CH}_{3}\right), 6.80(\mathrm{t}, 1$ $\left.\mathrm{H},{ }^{3} J_{\mathrm{HH}}=6.5 \mathrm{~Hz}, \mathrm{py} H\right), 7.14\left(\mathrm{~d}, 1 \mathrm{H},{ }^{3} J_{\mathrm{HH}}=7.5 \mathrm{~Hz}\right.$, py $\left.H\right), 7.39$ $\left(\mathrm{d}, 1 \mathrm{H},{ }^{3} J_{\mathrm{HH}}=8.0 \mathrm{~Hz}, \mathrm{py} H\right), 7.64-7.68(\mathrm{~m}, 2 \mathrm{H}, \mathrm{py} H), 7.85(\mathrm{~d}$, $\left.1 \mathrm{H},{ }^{3} J_{\mathrm{HH}}=8.0 \mathrm{~Hz}, \mathrm{py} H\right), 8.10(\mathrm{~s}, 1 \mathrm{H}, \mathrm{CH}=\mathrm{N}), 8.12\left(\mathrm{t}, 1 \mathrm{H},{ }^{3} J_{\mathrm{HH}}\right.$ $=8.0 \mathrm{~Hz}, \mathrm{py} H), 10.10(\mathrm{~s}, 1 \mathrm{H}, \mathrm{NH})$.

Bis[(6-formylpyridin-3-yl)methyl] (4R,5R)-2,2-Dimethyl-[1,3]dioxolane-4,5-dicarboxylate $((\boldsymbol{R}, \boldsymbol{R})-\mathbf{4})$. A solution of $(R, R)-\mathbf{2}(2.95$ $\mathrm{g}, 13 \mathrm{mmol})$ in dichloromethane $(50 \mathrm{~mL})$ was added slowly at 0 ${ }^{\circ} \mathrm{C}$ to solution of 5-(hydroxymethyl)pyridine-2-aldehyde, 3 (3.84 $\mathrm{g}, 28 \mathrm{mmol})$, triethylamine $(5.6 \mathrm{~mL}, 40 \mathrm{mmol})$, and 4-(dimethylamino)pyridine (DMAP) (cat.) in the same solvent $(50 \mathrm{~mL})$. The reaction mixture was warmed to room temperature, and then it was stirred for $2 \mathrm{~h}$. The resulting solution was washed with water, the organic layer separated and dried $\left(\mathrm{MgSO}_{4}\right)$, and the filtrate evaporated to dryness. The residue was subjected to flash chromatography on silica ( $1: 3 \mathrm{v} / \mathrm{v}$ ethyl acetate-dichloromethane) to afford the desired compound $\left(R_{f}=0.3\right)$ and unreacted 5-(hydroxymethyl)pyridine-2-aldehyde $\left(R_{f}=0.2\right)$. The pure product crystallized as colorless needles upon concentration of the eluate containing the band having $R_{f}=0.3$. Yield: $3.56 \mathrm{~g}(64 \%) ; \mathrm{mp}=77-81{ }^{\circ} \mathrm{C}$; $[\alpha]_{\mathrm{D}}^{18}=-26.9$ (c 1.0, $\left.\mathrm{CHCl}_{3}\right)$. Anal. Calcd for $\mathrm{C}_{21} \mathrm{H}_{20} \mathrm{~N}_{2} \mathrm{O}_{8}: \mathrm{C}$, 58.9; H, 4.7; N, 6.5. Found: C, 58.6; H, 4.8; N, 6.2. ${ }^{1} \mathrm{H}$ NMR $\left(\mathrm{CDCl}_{3}, 300 \mathrm{MHz}\right): \delta 1.45\left(\mathrm{~s}, 6 \mathrm{H}, \mathrm{CH}_{3}\right), 4.84(\mathrm{~s}, 2 \mathrm{H}, \mathrm{CH}), 5.33$ $\left(\mathrm{s}, 4 \mathrm{H}, \mathrm{CH}_{2}\right), 7.85\left(\mathrm{~d}, 2 \mathrm{H},{ }^{3} J_{\mathrm{HH}}=9.8 \mathrm{~Hz}, \mathrm{py} H\right), 7.95(\mathrm{~d}, 2 \mathrm{H}$, ${ }^{3} J_{\mathrm{HH}}=7.7 \mathrm{~Hz}$, pyH$), 8.77$ (s, $2 \mathrm{H}$, pyH-6), 10.10 (s, $\left.2 \mathrm{H}, \mathrm{CHO}\right)$.

Bis[(6- $(E)$-(pyridine-2-hydrazinylmethylene)pyridin-3-yl]methyl-(4R,5R)-2,2-dimethyl-[1,3]-dioxolane-4,5-dicarboxylate $((\boldsymbol{R}, \boldsymbol{R})-\mathbf{1})$. Pyridine-2-hydrazine $(1.53 \mathrm{~g}, 14 \mathrm{mmol})$ was dissolved in ethanol $(100 \mathrm{~mL})$ and added to $(R, R)-4(2.57 \mathrm{~g}, 6 \mathrm{mmol})$. The reaction mixture was heated under reflux for $30 \mathrm{~min}$, and then it was cooled; after $12-15 \mathrm{~h}$, the solution deposited the yellow microcrystalline product, which was isolated by filtration, washed with diethyl ether, and dried under vacuum. Yield: $2.93 \mathrm{~g} \mathrm{(80 \% )}$; $\mathrm{mp}=198-201{ }^{\circ} \mathrm{C} ;[\alpha]_{\mathrm{D}}^{18}=26.7$ (c 1.1, DMSO). Anal. Calcd for $\mathrm{C}_{31} \mathrm{H}_{30} \mathrm{~N}_{8} \mathrm{O}_{6}$ : C, 61.0; H, 5.0; N, 18.4. Found: C, 61.1; H, 5.1; N, 18.2. ${ }^{1} \mathrm{H} \mathrm{NMR}\left(\mathrm{CDCl}_{3}, 500 \mathrm{MHz}\right): \delta 1.54\left(\mathrm{~s}, 6 \mathrm{H}, \mathrm{CH}_{3}\right), 4.80(\mathrm{~s}$, $2 \mathrm{H}, \mathrm{CH}), 5.30\left(\mathrm{~d}, 2 \mathrm{H},{ }^{2} J_{\mathrm{HH}}=13.0 \mathrm{~Hz}, \mathrm{CH}_{2}\right), 5.36\left(\mathrm{~d}, 2 \mathrm{H},{ }^{2} J_{\mathrm{HH}}\right.$ $\left.=13.0 \mathrm{~Hz}, \mathrm{CH}_{2}\right), 6.82\left(\mathrm{t}, 2 \mathrm{H},{ }^{3} J_{\mathrm{HH}}=6.5 \mathrm{~Hz}, \mathrm{py} H\right), 7.22(\mathrm{~d}, 2 \mathrm{H}$, ${ }^{3} J_{\mathrm{HH}}=7.5 \mathrm{~Hz}$, pyH$), 7.41\left(\mathrm{~d}, 2 \mathrm{H},{ }^{3} J_{\mathrm{HH}}=9.0 \mathrm{~Hz}, \mathrm{py} H\right), 7.64-$ $7.68(\mathrm{~m}, 4 \mathrm{H}, \mathrm{py} H), 7.84\left(\mathrm{~d}, 2 \mathrm{H},{ }^{3} J_{\mathrm{HH}}=8.0 \mathrm{~Hz}, \mathrm{py} H\right), 7.92(\mathrm{~s}, 2$ $\mathrm{H}, \mathrm{CH}=\mathrm{N}), 8.12\left(\mathrm{~d}, 2 \mathrm{H},{ }^{3} J_{\mathrm{HH}}=6.5 \mathrm{~Hz}\right.$ pyH$)$. LR ESI-MS: $m / z$ $=611.4\left(32,[\mathrm{M}]^{+}\right), 633.4 \mathrm{amu}\left(100,[\mathrm{M}+\mathrm{Na}]^{+}\right)$.

$( \pm)$-[Fe(PAPHY $\left.)_{2}\right]\left(\mathbf{P F}_{6}\right)_{2}$. A solution of (hexaaqua)iron(II) sulfate-1-hydrate $(0.08 \mathrm{~g}, 0.27 \mathrm{mmol})$ and ammonium hexafluorophosphate $(0.4 \mathrm{~g}, 2.5 \mathrm{mmol})$ in water $(25 \mathrm{~mL})$ was treated with a solution of PAPHY $(0.1 \mathrm{~g}, 0.5 \mathrm{mmol})$ in ethyl methyl ketone (20 $\mathrm{mL}$ ). After $2 \mathrm{~h}$, the bright red organic phase was separated and evaporated to dryness. The pure product crystallized as dark red prisms from hot ethyl methyl ketone. Yield: $0.17 \mathrm{~g}(91 \%) ; \mathrm{mp}=$ $246{ }^{\circ} \mathrm{C}$ (dec). Anal. Calcd for $\mathrm{C}_{22} \mathrm{H}_{20} \mathrm{~F}_{12} \mathrm{FeN}_{8} \mathrm{P}_{2}$ : C, 35.6; H, 2.7; $\mathrm{N}, 15.1$. Found: $\mathrm{C}, 35.3 ; \mathrm{H}, 2.5 ; \mathrm{N}, 15.2 .{ }^{1} \mathrm{H}$ NMR (acetone- $d_{6}$, $500 \mathrm{MHz}): \delta 6.87\left(\mathrm{t}, 2 \mathrm{H},{ }^{3} J_{\mathrm{HH}}=7.0 \mathrm{~Hz}, \mathrm{py} H\right), 7.22\left(\mathrm{t}, 2 \mathrm{H},{ }^{3} J_{\mathrm{HH}}\right.$ 
$=6.5 \mathrm{~Hz}, \mathrm{py} H), 7.24\left(\mathrm{~d}, 2 \mathrm{H},{ }^{3} J_{\mathrm{HH}}=8.5 \mathrm{~Hz}, \mathrm{py} H\right), 7.73(\mathrm{t}, 2 \mathrm{H}$ $\left.{ }^{3} J_{\mathrm{HH}}=9.5 \mathrm{~Hz}, \mathrm{py} H\right), 7.83\left(\mathrm{~d}, 2 \mathrm{H},{ }^{3} J_{\mathrm{HH}}=5.5 \mathrm{~Hz}, \mathrm{py} H\right), 7.88(\mathrm{t}$, $\left.2 \mathrm{H},{ }^{3} J_{\mathrm{HH}}=7.5 \mathrm{~Hz}, \mathrm{py} H\right), 8.03\left(\mathrm{~d}, 2 \mathrm{H},{ }^{3} J_{\mathrm{HH}}=5.0 \mathrm{~Hz}, \mathrm{py} H\right), 8.06$ $\left(\mathrm{d}, 2 \mathrm{H},{ }^{3} \mathrm{~J}_{\mathrm{HH}}=5.5 \mathrm{~Hz}, \mathrm{py} H\right), 9.79(\mathrm{~s}, 2 \mathrm{H}, \mathrm{CH}=\mathrm{N})$. LR ESI-MS: $\mathrm{m} / \mathrm{z}=451.2\left(100,[\mathrm{M}+\mathrm{H}]^{+}\right), 226.2 \mathrm{amu}\left(81,[\mathrm{M}]^{2+}\right)$.

The Following Complexes were Prepared Similarly. $( \pm)$-[Fe-

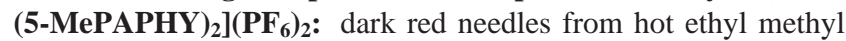
ketone; $\mathrm{mp}=245^{\circ} \mathrm{C}(\mathrm{dec}) ; 96 \%$ yield. Anal. Calcd for $\mathrm{C}_{24} \mathrm{H}_{24} \mathrm{~F}_{12^{-}}$ $\mathrm{FeN}_{8} \mathrm{P}_{2}$ : C, 37.4; H, 3.1; N, 14.5. Found: C, 36.5; H, 3.4; N, 14.0. ${ }^{1} \mathrm{H}$ NMR (acetone- $\left.d_{6}, 300 \mathrm{MHz}\right): \delta 2.11\left(\mathrm{~s}, 6 \mathrm{H}, \mathrm{CH}_{3}\right), 6.85(\mathrm{t}, 2$ $\left.\mathrm{H},{ }^{3} J_{\mathrm{HH}}=7.3 \mathrm{~Hz}, \mathrm{py} H\right), 7.20\left(\mathrm{~d}, 2 \mathrm{H},{ }^{3} J_{\mathrm{HH}}=8.4 \mathrm{~Hz}, \mathrm{py} H\right), 7.68-$ $7.72(\mathrm{~m}, 4 \mathrm{H}, \mathrm{py} H), 7.78\left(\mathrm{~d}, 2 \mathrm{H},{ }^{3} J_{\mathrm{HH}}=5.1 \mathrm{~Hz}, \mathrm{py} H\right), 7.88(\mathrm{~s}, 2$ $\mathrm{H}, \mathrm{py} H-6), 7.94\left(\mathrm{~d}, 2 \mathrm{H},{ }^{3} J_{\mathrm{HH}}=8.1 \mathrm{~Hz}, \mathrm{py} H\right), 9.72(\mathrm{~s}, 2 \mathrm{H}, \mathrm{CH}=$ N). LR FAB-MS: $m / z=480.2\left(33,[\mathrm{M}]^{+}\right), 479.1 \mathrm{amu}(100,[\mathrm{M}+$ $\left.\mathrm{H}^{+}\right)$. ( \pm -[Fe(6-MePAPHY $\left.)_{2}\right]\left(\mathbf{P F}_{6}\right)_{2}$ : dark red prisms from hot ethyl methyl ketone; $\mathrm{mp}=246-249{ }^{\circ} \mathrm{C} ; 96 \%$ yield. Anal. Calcd for $\mathrm{C}_{24} \mathrm{H}_{24} \mathrm{~F}_{12} \mathrm{FeN}_{8} \mathrm{P}_{2}$ : C, 37.4; H, 3.1; N, 14.5. Found: C, 37.4; $\mathrm{H}, 3.2 ; \mathrm{N}, 14.4 .{ }^{1} \mathrm{H}$ NMR (acetone- $\left.d_{6}, 500 \mathrm{MHz}\right): \delta 2.57(\mathrm{~s}, 6 \mathrm{H}$, $\left.\mathrm{CH}_{3}\right), 7.37\left(\mathrm{t}, 2 \mathrm{H},{ }^{3} J_{\mathrm{HH}}=8.0 \mathrm{~Hz}, \mathrm{py} H\right), 7.86\left(\mathrm{t}, 2 \mathrm{H},{ }^{3} J_{\mathrm{HH}}=7.5\right.$ $\mathrm{Hz}, \mathrm{py} H$ ), 8.62 (br s, $2 \mathrm{H}, \mathrm{py} H$ ), 8.71 (br s, 2H, py $H$ ), 9.14 (br s, 2H, py $H$ ), 9.29 (br s, $2 \mathrm{H}, \mathrm{py} H$ ), 11.55 (br s, $2 \mathrm{H}, \mathrm{CH}=\mathrm{N}$ ), 15.53 (br s, $2 \mathrm{H}, \mathrm{N} H$ ). LR ES-MS: $m / z 479.2\left(75,[\mathrm{M}-\mathrm{H}]^{+}\right), 213.2 \mathrm{amu}$ $\left(100,[(6-\mathrm{MePAPHY})+\mathrm{H}]^{+} .( \pm)-\left[\mathbf{F e}\left(\mathbf{5}-\mathbf{H O C H}_{2} \mathbf{P A P H Y}_{2}\right]\left(\mathbf{P F}_{6}\right)_{2}\right.\right.$ ( \pm )-7: dark red needles from hot ethyl methyl ketone; $\mathrm{mp}>250$ ${ }^{\circ} \mathrm{C}$; $90 \%$ yield. Anal. Calcd for $\mathrm{C}_{24} \mathrm{H}_{24} \mathrm{~F}_{12} \mathrm{FeN}_{8} \mathrm{O}_{2} \mathrm{P}_{2}$ : C, 35.9; $\mathrm{H}$, 3.0; N, 14.0. Found: C, 34.9; H, 3.4; N, 13.3. ${ }^{1} \mathrm{H}$ NMR (acetone$\left.d_{6}, 500 \mathrm{MHz}\right): \delta 4.45\left(\mathrm{~s}, 4 \mathrm{H}, \mathrm{CH}_{2}\right), 6.86\left(\mathrm{t}, 2 \mathrm{H},{ }^{3} J_{\mathrm{HH}}=6.0 \mathrm{~Hz}\right.$, py $H), 7.23\left(\mathrm{~d}, 2 \mathrm{H},{ }^{3} J_{\mathrm{HH}}=8.5 \mathrm{~Hz}, \mathrm{py} H\right), 7.72\left(\mathrm{t}, 2 \mathrm{H}^{3} J_{\mathrm{HH}}=7.5\right.$ $\mathrm{Hz}$, py $H), 7.81\left(\mathrm{~d}, 2 \mathrm{H},{ }^{3} J_{\mathrm{HH}}=5.0 \mathrm{~Hz}, \mathrm{py} H\right), 7.83\left(\mathrm{~d}, 2 \mathrm{H},{ }^{3} J_{\mathrm{HH}}=\right.$ $6.5 \mathrm{~Hz}, \mathrm{py} H), 7.97$ (s, $2 \mathrm{H}, \mathrm{py} H-6), 8.03\left(\mathrm{~d}, 2 \mathrm{H},{ }^{3} J_{\mathrm{HH}}=8.0 \mathrm{~Hz}\right.$, py $H), 9.79(\mathrm{~s}, 2 \mathrm{H}, \mathrm{C} H=\mathrm{N})$. LR ESI-MS: $m / z=511.1(100,[\mathrm{M}$ $\left.-\mathrm{H}]^{+}\right), 256.1$ amu $\left(76,[\mathrm{M}-\mathrm{H}]^{2+}\right)$.

$( \pm)$-[Fe(PAPY $\left.)_{2}\right]$. The protonated complex $( \pm)$-[Fe(PAPHY $\left.)_{2}\right]-$ $\left(\mathrm{PF}_{6}\right)_{2}(0.37 \mathrm{~g}, 0.50 \mathrm{mmol})$ in water $(10 \mathrm{~mL})$ was treated with $10 \%$ aq sodium hydroxide $(0.44 \mathrm{~mL}, 1.10 \mathrm{mmol})$. Dichloromethane (10 $\mathrm{mL}$ ) was added, and the mixture was stirred for $2 \mathrm{~h}$, after which time the organic phase was separated, dried $\left(\mathrm{MgSO}_{4}\right)$, and filtered; removal of the solvent from the filtate afforded the crude product, which was recrystallized from dichloromethane $-n$-hexane. The pure complex formed green-black prisms. Yield: $0.20 \mathrm{~g}(87 \%)$; $\mathrm{mp}>$ $250{ }^{\circ} \mathrm{C}$ [lit. $\left.{ }^{6}>250{ }^{\circ} \mathrm{C}\right] .{ }^{1} \mathrm{H}$ NMR $\left(\mathrm{CDCl}_{3}, 500 \mathrm{MHz}\right): \delta 6.10(\mathrm{t}, 2$ $\left.\mathrm{H},{ }^{3} \mathrm{~J}_{\mathrm{HH}}=6.5 \mathrm{~Hz}, \mathrm{py} H\right), 6.48\left(\mathrm{t}, 2 \mathrm{H},{ }^{3} J_{\mathrm{HH}}=7.0 \mathrm{~Hz}, \mathrm{py} H\right), 6.71$ $\left(\mathrm{d}, 2 \mathrm{H},{ }^{3} J_{\mathrm{HH}}=8.0 \mathrm{~Hz}, \mathrm{py} H\right), 7.01-7.03(\mathrm{~m}, 4 \mathrm{H}, \mathrm{py} H), 7.15-$ $7.19(\mathrm{~m}, 4 \mathrm{H}, \mathrm{py} H), 7.43\left(\mathrm{~d}, 2 \mathrm{H},{ }^{3} J_{\mathrm{HH}}=5.5 \mathrm{~Hz}, \mathrm{py} H\right), 9.02(\mathrm{~s}, 2$ $\mathrm{H}, \mathrm{C} H=\mathrm{N})$.

The Following Compounds were Prepared Similarly. $( \pm)$ [Fe(5-MePAPY $\left.)_{2}\right]$ : green-black prisms from dichloromethane$n$-hexane; mp $>250{ }^{\circ} \mathrm{C} ; 92 \%$ yield. Anal. Calcd for $\mathrm{C}_{24} \mathrm{H}_{22} \mathrm{FeN}_{8}$ : C, 60.3; H, 4.6; N, 23.4. Found: C, 60.4; H, 4.6; N, 22.9. ${ }^{1} \mathrm{H}$ NMR $\left(\mathrm{CD}_{2} \mathrm{Cl}_{2}, 500 \mathrm{MHz}\right): \delta 1.98\left(\mathrm{~s}, 6 \mathrm{H}, \mathrm{CH}_{3}\right), 6.00\left(\mathrm{t}, 2 \mathrm{H},{ }^{3} J_{\mathrm{HH}}=6.5\right.$ $\mathrm{Hz}, \mathrm{py} H), 6.54\left(\mathrm{~d}, 2 \mathrm{H},{ }^{3} J_{\mathrm{HH}}=8.0 \mathrm{~Hz}, \mathrm{py} H\right), 6.93-6.89(\mathrm{~m}, 4 \mathrm{H}$, py $H), 7.02\left(\mathrm{~d}, 2 \mathrm{H},{ }^{3} J_{\mathrm{HH}}=8.5 \mathrm{~Hz}, \mathrm{py} H\right), 7.08\left(\mathrm{~d}, 2 \mathrm{H},{ }^{3} J_{\mathrm{HH}}=6.5\right.$ $\mathrm{Hz}, \mathrm{py} H), 7.24$ (s, $2 \mathrm{H}$, pyH-6), 8.89 (s, $2 \mathrm{H}, \mathrm{CH}=\mathrm{N})$. LR ESIMS: $m / z=478\left(100,[\mathrm{M}]^{+}\right), 267$ amu $(45,[\mathrm{Fe}+(5-\mathrm{MePA}-$ PHY $\left.)]^{+}\right) .( \pm)-\left[\mathbf{F e}(6-M e P A P Y)_{2}\right]$ : green-black prisms from dichloromethane- $n$-hexane; $\mathrm{mp}>250{ }^{\circ} \mathrm{C}$ [lit. $\left.{ }^{6}>250{ }^{\circ} \mathrm{C}\right]$; $90 \%$ yield. ${ }^{1} \mathrm{H} \mathrm{NMR}\left(\mathrm{CDCl}_{3}, 500 \mathrm{MHz}\right): \delta 2.46\left(\mathrm{~s}, 6 \mathrm{H}, \mathrm{CH}_{3}\right), 6.09(\mathrm{t}, 2 \mathrm{H}$, $\left.{ }^{3} J_{\mathrm{HH}}=6.0 \mathrm{~Hz}, \mathrm{py} H\right), 6.31\left(\mathrm{~d}, 2 \mathrm{H},{ }^{3} J_{\mathrm{HH}}=7.5 \mathrm{~Hz}, \mathrm{py} H\right), 6.73(\mathrm{~d}$, $\left.2 \mathrm{H},{ }^{3} J_{\mathrm{HH}}=8.5 \mathrm{~Hz}, \mathrm{py} H\right), 6.82\left(\mathrm{~d}, 2 \mathrm{H},{ }^{3} J_{\mathrm{HH}}=5.5 \mathrm{~Hz}, \mathrm{py} H\right)$, 6.96-7.00 (m, $4 \mathrm{H}, \mathrm{py} H), 7.16\left(\mathrm{t}, 2 \mathrm{H},{ }^{3} \mathrm{~J}_{\mathrm{HH}}=8.0 \mathrm{~Hz}, \mathrm{py} H\right), 9.34$ (s, $2 \mathrm{H}, \mathrm{CH}=\mathrm{N})$.

$( \pm)$-[ $\left.\mathrm{Fe}\left(5-\mathrm{HOCH}_{2} \mathrm{PAPY}\right)_{2}\right]$. The protonated complex $( \pm)-[\mathrm{Fe}-$ $\left.\left(5-\mathrm{HOCH}_{2} \mathrm{PAPHY}\right)_{2}\right]\left(\mathrm{PF}_{6}\right)_{2}(0.40 \mathrm{~g}, 0.5 \mathrm{mmol})$ was dissolved in methanol $(20 \mathrm{~mL})$, and the solution was treated with $10 \%$ aq sodium hydroxide $(0.44 \mathrm{~mL}, 1.10 \mathrm{mmol})$. The dark green-black solution was concentrated to afford the crude product as a fine brownblack powder, which was recrystallized from hot methanol. The pure complex was thus obtained as a brown-black, microcrystalline powder. Yield: $0.23 \mathrm{~g}(92 \%) ; \mathrm{mp}>250{ }^{\circ} \mathrm{C}$. Anal. Calcd for $\mathrm{C}_{24} \mathrm{H}_{22} \mathrm{FeN}_{8} \mathrm{O}_{2}$ : C, 56.5; H, 4.3; N, 22.0. Found: C, 56.2; $\mathrm{H}$, 4.4; N, 21.8. ${ }^{1} \mathrm{H}$ NMR $\left(\mathrm{CD}_{3} \mathrm{OD}, 500 \mathrm{MHz}\right): \delta 4.25\left(\mathrm{~s}, 4 \mathrm{H}, \mathrm{CH}_{2}\right)$, $6.18\left(\mathrm{t}, 2 \mathrm{H},{ }^{3} \mathrm{~J}_{\mathrm{HH}}=8.5 \mathrm{~Hz}, \mathrm{py} H\right), 6.64\left(\mathrm{~d}, 2 \mathrm{H},{ }^{3} \mathrm{~J}_{\mathrm{HH}}=8.5 \mathrm{~Hz}\right.$, py $H), 7.09-7.12(\mathrm{~m}, 4 \mathrm{H}, \mathrm{py} H), 7.27\left(\mathrm{~d}, 2 \mathrm{H},{ }^{3} J_{\mathrm{HH}}=8.0 \mathrm{~Hz}, \mathrm{py} H\right)$, $7.34\left(\mathrm{~d}, 2 \mathrm{H},{ }^{3} J_{\mathrm{HH}}=7.0 \mathrm{~Hz}, \mathrm{py} H\right), 7.46(\mathrm{~s}, 2 \mathrm{H}, \mathrm{pyH}-6), 9.08(\mathrm{~s}$, $2 \mathrm{H}, \mathrm{CH}=\mathrm{N})$. LR ESI-MS: $m / z=510.1\left(82,[\mathrm{M}]^{+}\right), 256.1 \mathrm{amu}$ $\left(100,[\mathrm{M}]^{2+}\right)$.

$\left(P_{\mathrm{Fe}}\right)-(-)-[\mathrm{Fe}\{(\boldsymbol{R}, \boldsymbol{R})-\mathbf{1}\}]\left(\mathrm{PhSO}_{3}\right)_{2}\left(\left(\boldsymbol{P}_{\mathrm{Fe}}\right)-(-)-5\right)$. Hexaaquairon(II) benzenesulfonate $(0.12 \mathrm{~g}, 0.25 \mathrm{mmol})$ was dissolved in methanol $(80 \mathrm{~mL})$, and the solution was added dropwise over $1 \mathrm{~h}$ to a suspension of $(R, R)-1(0.15 \mathrm{~g}, 0.25 \mathrm{mmol})$ in the same solvent (200 $\mathrm{mL}$ ). The solution was stirred for $2 \mathrm{~h}$ at room temperature, and then it was filtered. Removal of the solvent from the filtrate under reduced pressure afforded the crude product as a red solid, which crystallized as red needles from ethanol-water-diethyl ether. Yield: $0.24 \mathrm{~g}(97 \%) ; \mathrm{mp}=227-230{ }^{\circ} \mathrm{C} ;[\alpha]_{\mathrm{D}}^{18}=-838(c 0.014$, $\mathrm{MeOH}$ ). Anal. Calcd for $\mathrm{C}_{43} \mathrm{H}_{38} \mathrm{FeN}_{8} \mathrm{O}_{12} \mathrm{~S}_{2}$ : C, 52.8; H, 3.9; N, 11.5. Found: $\mathrm{C}, 52.6 ; \mathrm{H}, 4.4 ; \mathrm{N}, 11.4 .{ }^{1} \mathrm{H}$ NMR $\left(\mathrm{CD}_{3} \mathrm{OD}, 500\right.$ $\mathrm{MHz}): \delta 1.41\left(\mathrm{~s}, 6 \mathrm{H}, \mathrm{CH}_{3}\right), 3.94(\mathrm{~s}, 2 \mathrm{H}, \mathrm{CH}), 4.70\left(\mathrm{~d}, 2 \mathrm{H},{ }^{2} J_{\mathrm{HH}}\right.$ $\left.=11.0 \mathrm{~Hz}, \mathrm{CH}_{2}\right), 5.21\left(\mathrm{~d}, 2 \mathrm{H},{ }^{2} J_{\mathrm{HH}}=11.0 \mathrm{~Hz}, \mathrm{CH}_{2}\right), 6.86(\mathrm{t}, 2 \mathrm{H}$, ${ }^{3} J_{\mathrm{HH}}=6.5 \mathrm{~Hz}$, pyH$), 7.06\left(\mathrm{~d}, 2 \mathrm{H},{ }^{3} J_{\mathrm{HH}}=8.5 \mathrm{~Hz}, \mathrm{py} H\right), 7.41-$ $7.44\left(\mathrm{~m}, 4 \mathrm{H}\right.$, pyH and $\left.\mathrm{PhSO}_{3}{ }^{-}\right), 7.94\left(\mathrm{~d}, 2 \mathrm{H},{ }^{3} J_{\mathrm{HH}}=8.5 \mathrm{~Hz}\right.$, py $H), 9.71(\mathrm{~s}, 2 \mathrm{H}, \mathrm{CH}=\mathrm{N}) .{ }^{13} \mathrm{C}\left\{{ }^{1} \mathrm{H}\right\} \mathrm{NMR}\left(\mathrm{CD}_{3} \mathrm{OD}, 125 \mathrm{MHz}\right)$ : $\delta 26.3,64.6,78.3,108.6,115.2,121.0,125.8,126.8,127.0,129.4$, 131.4, 135.2, 141.1, 141.4, 147.2, 150.1, 155.3, 159.6, 160.8, 168.8. HR ESI-MS: $m / z=665.1576($ calcd 665.1559$) \mathrm{amu}[\mathrm{M}-\mathrm{H}]^{+}$. Crystals of the mixed solvate $\left(P_{\mathrm{Fe}}\right)-(-)-5 \cdot 2 \mathrm{CH}_{3} \mathrm{OH} \cdot 3 \mathrm{H}_{2} \mathrm{O}$ were obtained by the diffusion of diethyl ether into a concentrated solution of the complex in $95 \%$ aq methanol; the crystals were suitable for X-ray crystallography.

$\left(\boldsymbol{P}_{\mathrm{Fe}}\right)-(+)-[\mathbf{F e}\{((\boldsymbol{R}, \boldsymbol{R})-\mathbf{1 - 2 H})\}] \quad\left(\left(\boldsymbol{P}_{\mathrm{Fe}}\right)-(+)-\mathbf{6}\right)$. The protonated complex $\left(P_{\mathrm{Fe}}\right)-(-)-5(0.20 \mathrm{~g}, 0.20 \mathrm{mmol})$ was suspended in water $(5 \mathrm{~mL})$, and $10 \%$ aq sodium hydroxide $(0.16 \mathrm{~mL}, 0.40 \mathrm{mmol})$ was added. Dichloromethane $(5 \mathrm{~mL})$ was added, and the mixture was stirred for $30 \mathrm{~min}$. The organic layer was separated, dried $\left(\mathrm{MgSO}_{4}\right)$, and the solvent was removed from the filtrate to furnish the deprotonated complex as a green-brown solid. Yield: $0.13 \mathrm{~g}$ (97\%); mp > $250{ }^{\circ} \mathrm{C} ;[\alpha]_{\mathrm{D}}^{18}=+1474$ (c 0.026, MeOH). Anal. Calcd for $\mathrm{C}_{31} \mathrm{H}_{28} \mathrm{FeN}_{8} \mathrm{O}_{6}$ : C, 56.0; $\mathrm{H}, 4.3 ; \mathrm{N}, 16.9$. Found: C, 56.8; $\mathrm{H}, 4.6$; N, 15.1. ${ }^{1} \mathrm{H}$ NMR $\left(\mathrm{C}_{6} \mathrm{D}_{6}, 500 \mathrm{MHz}\right): \delta 1.37\left(\mathrm{~s}, 6 \mathrm{H}, \mathrm{CH}_{3}\right)$, $3.34\left(\mathrm{~d}, 2 \mathrm{H},{ }^{2} J_{\mathrm{HH}}=11.5 \mathrm{~Hz}, \mathrm{CH}_{2}\right), 4.24(\mathrm{~s}, 2 \mathrm{H}, \mathrm{CH}), 4.50(\mathrm{~d}, 2$ $\left.\mathrm{H},{ }^{2} J_{\mathrm{HH}}=11.5 \mathrm{~Hz}, \mathrm{CH}_{2}\right), 5.79\left(\mathrm{t}, 2 \mathrm{H},{ }^{3} J_{\mathrm{HH}}=6.5 \mathrm{~Hz}, \mathrm{py} H\right), 6.21$ $\left(\mathrm{d}, 2 \mathrm{H},{ }^{3} J_{\mathrm{HH}}=8.0 \mathrm{~Hz}, \mathrm{py} H\right), 6.56\left(\mathrm{t}, 2 \mathrm{H},{ }^{3} J_{\mathrm{HH}}=8.0 \mathrm{~Hz}, \mathrm{py} H\right)$, $6.66\left(\mathrm{~d}, 2 \mathrm{H},{ }^{3} J_{\mathrm{HH}}=8.5 \mathrm{~Hz}, \mathrm{py} H\right), 6.97(\mathrm{~d}, 2 \mathrm{H}, \mathrm{py} H)$ (obscured by singlet at 6.99), $6.99(\mathrm{~s}, 2 \mathrm{H}, \mathrm{py} H-6), 7.46\left(\mathrm{~d}, 2 \mathrm{H},{ }^{3} J_{\mathrm{HH}}=5.5\right.$ $\mathrm{Hz}, \mathrm{py} H), 9.15(\mathrm{~s}, \mathrm{C} H=\mathrm{N})$. HR ESI-MS: $m / z=665.1526(\mathrm{calcd}$ 665.1559) amu $[\mathrm{M}+\mathrm{H}]^{+}$.

Saponification of $\left(\boldsymbol{P}_{\mathrm{Fe}}\right)-(-)-5:\left(\boldsymbol{P}_{\mathrm{Fe}}\right)-(+)-7$. The pure diastereomer $\left(P_{\mathrm{Fe}}\right)-(-)-5(0.5 \mathrm{~g}, 0.5 \mathrm{mmol})$ was dissolved in water $(30$ $\mathrm{mL}$ ), and the solution was treated with $10 \%$ aq sodium hydroxide $(0.80 \mathrm{~mL}, 2 \mathrm{mmol})$. The dark brown-black precipitate of the saponified product $(P)-(+)-7$ that precipitated was isolated by filtration, washed with water and diethyl ether, and dried in vacuo. Yield: $0.22 \mathrm{~g}(85 \%) ; \mathrm{mp}>250{ }^{\circ} \mathrm{C} ;[\alpha]_{\mathrm{D}}^{18}=+601$ (c 0.009 , $\mathrm{MeOH}$ ) (No change in this value was observed over 3 days). ${ }^{1} \mathrm{H}$ $\mathrm{NMR}\left(\mathrm{CD}_{3} \mathrm{OD}, 500 \mathrm{MHz}\right)$ : identical with spectrum of corresponding racemate. 
Determination of Enantiomeric Purity of $\left(\boldsymbol{P}_{\mathrm{Fe}}\right)-(+)-7$. The racemic complex $( \pm)-7(0.012 \mathrm{~g}, 0.023 \mathrm{mmol})$ was dissolved in methanol $(1 \mathrm{~mL})$, and 1.5 equiv of $(\mathrm{a} R)-8(0.012 \mathrm{~g}, 0.035 \mathrm{mmol})$ was added. After $15 \mathrm{~min}$, dichloromethane $(5 \mathrm{~mL})$ and water $(5$ $\mathrm{mL}$ ) were added and the mixture was stirred for $30 \mathrm{~min}$. The two phases were separated, the dichloromethane phase washed with water, dried $\left(\mathrm{MgSO}_{4}\right)$, and filtered. Evaporation of the filtrate afforded the protonated racemate as a pink powder. ${ }^{1} \mathrm{H} \mathrm{NMR}\left(\mathrm{CD}_{2^{-}}\right.$ $\left.\mathrm{Cl}_{2}, 500 \mathrm{MHz}\right): \delta 9.50\left(\mathrm{~s}, 2 \mathrm{H}, \mathrm{CH}=\mathrm{N}, P_{\mathrm{Fe}}\right), 9.45(\mathrm{~s}, 2 \mathrm{H}, \mathrm{CH}=\mathrm{N}$, $\left.M_{\mathrm{Fe}}\right)$. The corresponding reaction with the product of the asymmetric synthesis, $\left(P_{\mathrm{Fe}}\right)-(-)-7$, afforded a similar solid. ${ }^{1} \mathrm{H} \mathrm{NMR}\left(\mathrm{CD}_{2} \mathrm{Cl}_{2}\right.$, $500 \mathrm{MHz}): \delta 9.50\left(\mathrm{~s}, 2 \mathrm{H}, \mathrm{CH}=\mathrm{N}, P_{\mathrm{Fe}}\right)(85 \%), 9.45(\mathrm{~s}, 2 \mathrm{H}, \mathrm{CH}=$ $\left.\mathrm{N}, M_{\mathrm{Fe}}\right)(15 \%)$.
Crystal Structures. Crystal data and experimental parameters for $\left(P_{\mathrm{Fe}}\right)-(-)-\mathbf{5} \cdot 2 \mathrm{CH}_{3} \mathrm{OH} \cdot 3 \mathrm{H}_{2} \mathrm{O}$ are given in Table 1 . The absolute configuration of the complex was established by refinement of the Flack parameter, final value -0.010 (11), and knowledge of the absolute configuration of the $(2 R, 3 R)-(+)$-tartaric acid used for the synthesis of the ligand $(R, R)-\mathbf{1}$.

Supporting Information Available: Additional crystallographic data in CIF format. This material is available free of charge via the Internet at http://pubs.acs.org.

IC060856Q 